\title{
The relationships between alcohol, wine and cardiovascular diseases - A review
}

\author{
Creina S. Stockley* \\ The Australian Wine Research Institute, Glen Osmond, South Australia, Australia
}

\begin{abstract}
The relationship between alcohol consumption and the risk of cardiovascular disease has now been studied for over fifty years, and confirmed in multiples case-controlled and cohort studies, and subsequent meta-analyses of these studies. Sound experimental and clinical studies of plausible biological mechanisms support that there is a causal relationship between alcoholic beverages and cardiovascular disease. While beer, wine and spirits all contain alcohol, they are not necessarily equal in their effects on cardiovascular health, such as the incidence and mortality of coronary heart disease, stroke and all-cause mortality. Hence this review evaluates the available evidence, and details the biological mechanisms and attributes a percentage reduction in harm where possible.
\end{abstract}

Keywords: Alcohol, wine, cardiovascular disease, coronary heart disease, myocardial infarction

\section{Introduction}

Cardiovascular disease (CVD) in its various clinical manifestations, for example, hypertension, coronary (artery) heart disease, myocardial infarction (MI), congestive heart failure and stroke, still represents a major public health and financial burden worldwide despite knowledge of modifiable risk factors and accessibility to drug and non-drug therapies [1].

CVD involves a complex interplay between multiple altered cellular and molecular functions in heart muscle (such as cardiomyocytes), blood vessels (such as endothelial cells), vascular smooth muscle cells, blood cells (such as platelets and monocytes) and plasma components (such as lipoproteins, and blood clotting and blood flow factors) as well as gene function [2]. Accordingly, there are multiple biological mechanisms involved in reducing the risk of cardiovascular diseases, including haemostatic effects on a blood pressure and blood flow, anti-inflammatory effects and enhanced endothelial

\footnotetext{
*Corresponding author: Creina S. Stockley, The Australian Wine Research Institute, PO Box 197, Glen Osmond, South Australia 5061, Australia. Tel.: +61 883136600; Fax: +61 883136601; E-mail: creina.stockley@awri.com.au.
}

function, that is the ability of the artery wall to expand and contract, thus providing a protective effect during the early phases of atherosclerosis [3-6]. Atherosclerosis is the underlying cause of most cardiovascular diseases. The lining of the artery wall (endothelium) plays a crucial role in regulating blood flow and the supply of oxygen to organs and tissues through the production of nitric oxide [7]. Nitric oxide regulates arterial tone, that is, how much the arteries resist being stretched, and exerts significant anti-inflammatory and anti-atherosclerotic effects [7]. Endothelial dysfunction, which is the inability of the lining of the artery wall to expand and contract, has been shown to be an independent predictor of cardiovascular disease even after adjusting for traditional risk factors such as hypertension and hypercholesterolaemia, which are characterised by an impairment of endothelium-dependent vasodilatation [8]. Atherosclerotic lesions are also commonly observed in the peripheral arteries of patients with the inter-related peripheral artery disease.

While CVD is the leading cause of death in developed countries accounting for $25-50 \%$ of all deaths, its incidence varies 10-fold across different countries $[9,10]$. Sources of the variation across different countries include differences in the risk factors for cardiovascular disease, such as body mass index 
(BMI), diet and exercise, disease status, in particular diabetes mellitus, genetic predisposition, medical intervention and treatment, systolic blood pressure, serum cholesterol concentration, balance between high and low density lipoprotein, cigarette smoking and socioeconomic status as well as differences in the amount, pattern and even type of alcoholic beverage consumed $[11,12]$.

Between 1980 and 2006, Australia had one of the greatest declines in CVD death rates compared to the other OECD countries. In 2009, however, CVDrelated deaths still accounted for $32.8 \%$ of the total number of deaths in Australia, and $18 \%$ of the overall burden of disease in Australia [13, 14]. Coronary heart disease (CHD) and stroke contributed over $80 \%$ of this burden. For example, CHD deaths accounted for $49 \%$ of all CVD deaths and $16 \%$ of deaths from all causes and stroke deaths accounted for $18 \%$ of CVD deaths and 6\% of all deaths. From the WHO's Global Status Report on Alcohol and Health 2014, Australian per capita alcohol consumption has been stable over the last decade at approximately $10.4 \mathrm{~L}$ of pure alcohol. Also, its patterns of drinking score is calculated to be two, where one is least risky drinking pattern and five is most risky [15].

Improving haemostatic effects, anti-inflammatory effects and endothelial function associated with CVD by means of non-drug therapies such as the inclusion of the moderate consumption of alcoholic beverages, and in particular wine, in the daily diet might represent an important therapeutic target $[8,16]$.

This review paper discusses the available published literature on the relationships between CVD and the consumption of alcoholic beverages, and specifically wine, through a systematic search of the electronic database PUBMED from January 1980 up to May 2014. The published literature includes meta-analyses, relevant reviews, experimental and clinical studies, and references of identified papers, but excluded letters, editorials, conference abstracts and commentaries. No language restrictions were applied.

\section{Relationship between alcohol consumption and CVD - Early studies}

The primary classifications of alcoholic beverages are wine, beer and spirits, the consumption of which depends on the country and its cultures [17]. All alcoholic beverages contain alcohol as their characterising ingredient. Wine, for example, typically contains the following alcohols in measurable amounts: methyl, ethyl, n-propyl, iso-propyl, isobutyl, iso-amyl, act-amyl, 2-phenethanol, n-hexanol as well as detectable amounts of approximately 18 other alcohols [18]. The most abundant alcohol is ethyl alcohol or ethanol, where the concentration of ethanol in 'table' wine generally ranges between 8 and $15 \% \mathrm{v} / \mathrm{v}$ [19].

In 1915, the first description was published of a relationship between the prevalence of hypertension and the amount of alcohol consumed by French Troops on the western front during World War I [20]. A J-shaped relationship between amount of alcohol consumed and risk of cardiovascular diseases such as hypertension was first observed in 1974 by Klatsky et al. and independently by St Leger et al. in 1979 (Fig. 1A) [21, 22].

Thirty-five years later, there is now an accepted inverse relationship between moderate alcohol consumption and CVD that is acknowledged by the World Health Organisation [23, 24]. For example, the WHO's Global Status Report on Alcohol 2011 and reiterated in the 2014 version, includes the following statement: "The relationship between alcohol consumption and cardiovascular diseases is complex [15, 25]. Light to moderate drinking can have a beneficial impact on morbidity and mortality for ischaemic heart disease and ischaemic stroke. However, the beneficial cardioprotective effect of drinking disappears with heavy drinking occasions."

Initial observations of the 1970s have been followed by a series of large scale, cross-sectional, longitudinal and prospective epidemiological studies (Fig. 1B). Almost all of these studies have demonstrated a J-shaped relationship between the consumption of alcoholic beverages such as wine, and the risk of, and death from, CVD [26-39]. The risk of CVD is decreased with moderate consumption compared to abstinence but increases again with heavier consumption [40].

\section{Relationship between alcohol consumption and CVD - Later studies and meta-analyses}

It has been suggested that confounding may have lead to bias in the majority of the studies that were undertaken between 1974 and 2005, and consequently that any cardioprotection afforded by 
A

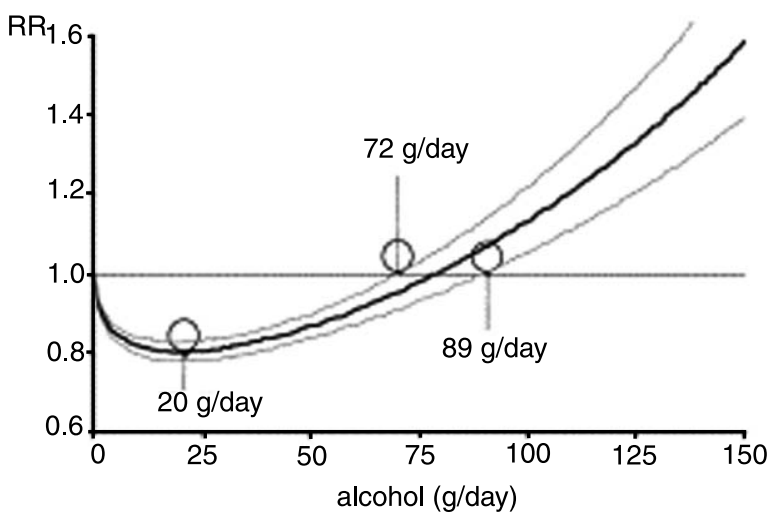

B
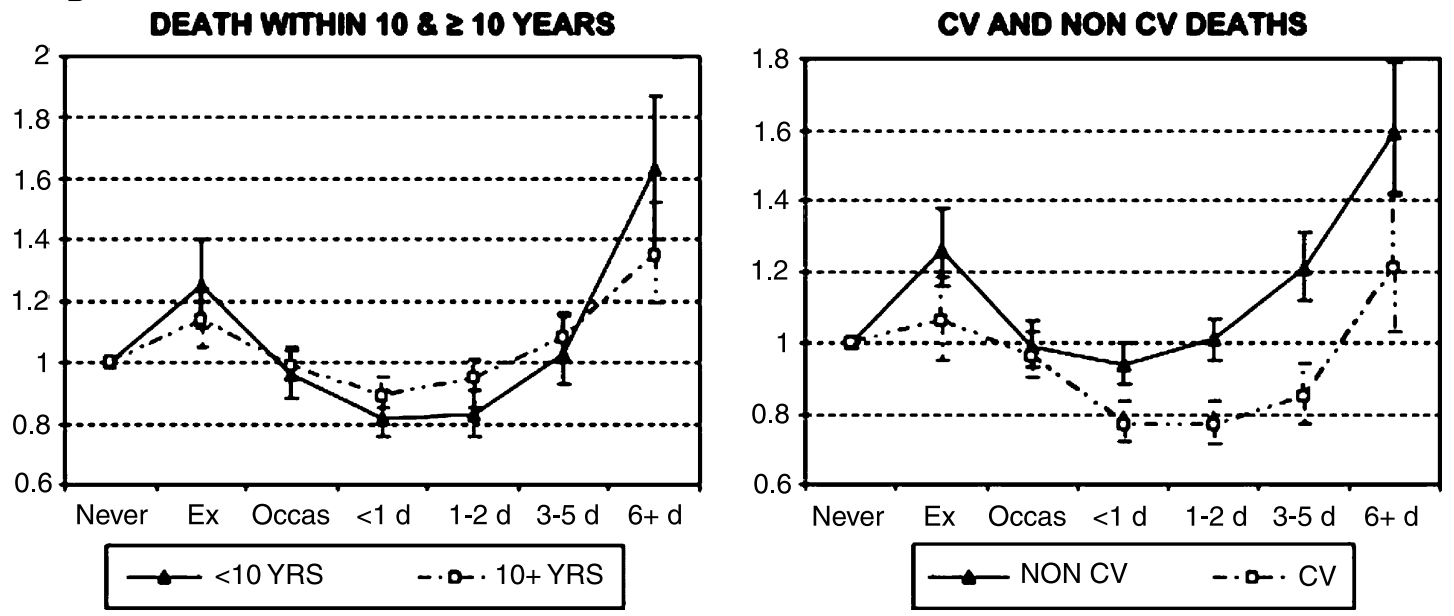

Fig. 1. A) J-shaped curve from meta-analysis by Corrao et al. 2004. Relative risk function and corresponding 95\% confidence intervals describing the dose-response relationship between alcohol consumption and the risk of coronary heart disease. From: Corrao G, Bagnardi V, Zambon A, La Vecchia C. 2004. A meta-analysis of alcohol consumption and the risk of 15 diseases. Prev Med. 38(5):613-9. [41]. B) J-shaped curve from re-analysis of data by Klatsky and Udaltsova 2007 [42]. Fully adjusted model for interval between baseline data and death (left hand side figure) where all relations appear to become attenuated with passage of time. This probably is due to a general reduction of alcohol intake in the population, resulting in less harm from heavy drinking and less benefit from light-moderate drinking. Fully adjusted model for cardiovascular $(\mathrm{CV})$ and non-cardiovascular (non-CV) deaths (right hand side figure).

alcoholic beverages had been overestimated [43-45]. The suggested confounding was misclassification of ex-drinkers who are at higher risk of ischaemic heart disease in the abstainer category, thereby inflating the risk of abstainers compared with moderate drinkers. Ischaemic heart disease is also referred to as coronary heart disease.

\subsection{Later studies}

Reanalysis of the earlier studies [42, 46] and subsequent studies undertaken that have separated ex-drinkers from lifetime abstainers [47-58], all show that most of these earlier studies still support a
J-shaped relationship between alcohol consumption and CVD. Ex-drinkers, lifetime abstainers and heavy consumers all show increased CVD and mortality risks compared to moderate consumers. By consensus, heavy consumption is generally considered to be greater than $30-40 \mathrm{~g}$ alcohol/day, while moderate consumption is less than $30-40 \mathrm{~g}$ alcohol/day. Cardioprotection has been consistently observed for both men [50] and women [59] in diverse ethnic populations [60-67]. It is also generally observed when controlling for known confounding factors such as body mass index (BMI), cigarette smoking, diet and exercise [50, 57, 68-73]. Indeed, Rimm and Moats (2007) addressed the issue of residual confounding by healthy lifestyle in drinkers in a large prospective 
study by restricting analysis to only 'healthy' men (who did not smoke cigarettes, exercised, ate a healthy diet, and were not overweight) [52]. Within this group, men who consumed alcohol moderately had a $62 \%(11-84 \%)$ reduced risk for CHD compared with lifetime abstainers, providing further evidence to support the hypothesis that the inverse association of alcohol to CHD is causal, and not confounded by healthy lifestyle behaviours.

In addition, Fuller (2011) and Rostron (2011) independently analysed for both the frequency as well as quantity of alcohol consumption $[46,58]$. When lifetime occasional moderate drinkers rather than lifetime abstainers was used as the reference consumption category, regular moderate consumers had the lowest risk of CVD mortality (13\% for men and $20 \%$ for women) when compared with all consumption categories. Indeed, the risk of CVD mortality was not significantly higher for regular heavy consumers than it was for occasional moderate consumers [46, $58,74]$, although this was not observed for all-cause mortality. The reduction in CVD mortality is largely related to the reduction in the risk of coronary (artery) heart disease, which is the major cause of CVD mortality.

\subsection{Meta-analyses}

Through a systematic search of the electronic database PUBMED from January 1980 up to May 2014, 20 published papers of meta-analyses on the relationship of alcohol consumption to CVD were identified which is shown in Table 1. Two metaanalyses assessed cardiovascular disease per se, seven coronary heart disease, one myocardial infarction, one heart failure, two atrial fibrillation, two hypertension, three stroke and three all-cause mortality. No meta-analyses specifically assessed peripheral artery disease. Studies from at least 20 different countries were included, and not all meta-analyses included the same studies. None of the meta-analyses differentiated between different types of alcoholic beverages.

From the analysis of eight prospective studies (five cohort and three randomized studies) from 1988 to 2008 , encompassing 16,351 subjects, which all showed a J-shaped relationship between alcohol consumption and CVD, Constanzo et al. (2012) calculated that the percentage reduction in risk was $22 \%$ (13-30\%), where the optimal amount associated with this reduction was between 8 to $26 \mathrm{~g}$ alcohol/day [75]. A more conservative calculation of a 0.6 to $1.8 \%$ reduction in risk for women and men, respectively, was made by Inoue et al. (2012) on six Japanese cohort studies which was associated with up to $46 \mathrm{~g}$ alcohol/day for women and less than $69 \mathrm{~g}$ alcohol/day for men [76].

When myocardial infarction was specifically considered, the reduction in risk was calculated to be $18 \%(11-24 \%)$ for $10 \mathrm{~g}$ alcohol/day by Maclure (1993) from 42 cohort studies from 1968 to 1993 that encompassed 52,364 subjects [77]. All five meta-analyses consistently calculated a J-shaped relationship between alcohol consumption and CVD [41, 78-80] including that of Fillmore et al. [44]. From six prospective studies undertaken from 2001 to 2007 and encompassing 164,479 subjects, Padilla et al. (2010) calculated that the reduction in risk of heart failure was $23 \%$ (5-37\%) with less than $140 \mathrm{~g}$ alco$\mathrm{hol} /$ week, or approximately $10 \mathrm{~g}$ alcohol/day [81].

A recent review of 44 cohort and case-control studies undertaken from 1980 to 2010 on alcohol consumption and coronary heart disease calculated a $25 \%(0.12$ to $36 \%)$ and $46 \%$ (35 to $55 \%$ ) reduced risk of developing coronary heart disease for men and women, respectively [81]. This was observed at an average intake of $63 \mathrm{~g}$ alcohol/day for men but only $14 \mathrm{~g} /$ day for women. Alcohol consumption in men, however, was associated with a linear dose response relationship and detrimental effects for other diseases such as cancers, hypertension, liver cirrhosis and pancreatitis as well as injuries and violence [41]. Corrao et al. (2004) only observed a similar maximal reduced coronary heart disease risk at $20 \mathrm{~g}$ alcohol/day for men and women, although cardioprotection was observed up to $72 \mathrm{~g} /$ day [41] The corresponding maximal reduced risk of coronary heart disease mortality was calculated as $22 \%(0.3$ to $37 \%)$ at $31 \mathrm{~g}$ alcohol/day for men and $18 \%(0.4$ to $26 \%$ ) at $11 \mathrm{~g} /$ day for women. The studies all had life-time abstainers as the reference category to avoid the confounding proposed by Fillmore et al. (2006) and to provide strength of the evidence of a cardioprotective and causal association. Indeed the authors concluded that "based on our meta-analysis, some form of cardioprotective association for ischaemic heart disease [coronary heart disease] morbidity and mortality is hard to deny, given epidemiological evidence". The gender difference in the calculated risk probably reflects the different physiology of men and women. For example, women typically have lower body weight, smaller liver capacity to metabolize alcohol, and a higher proportion of body fat, which together contribute to women achieving higher blood 


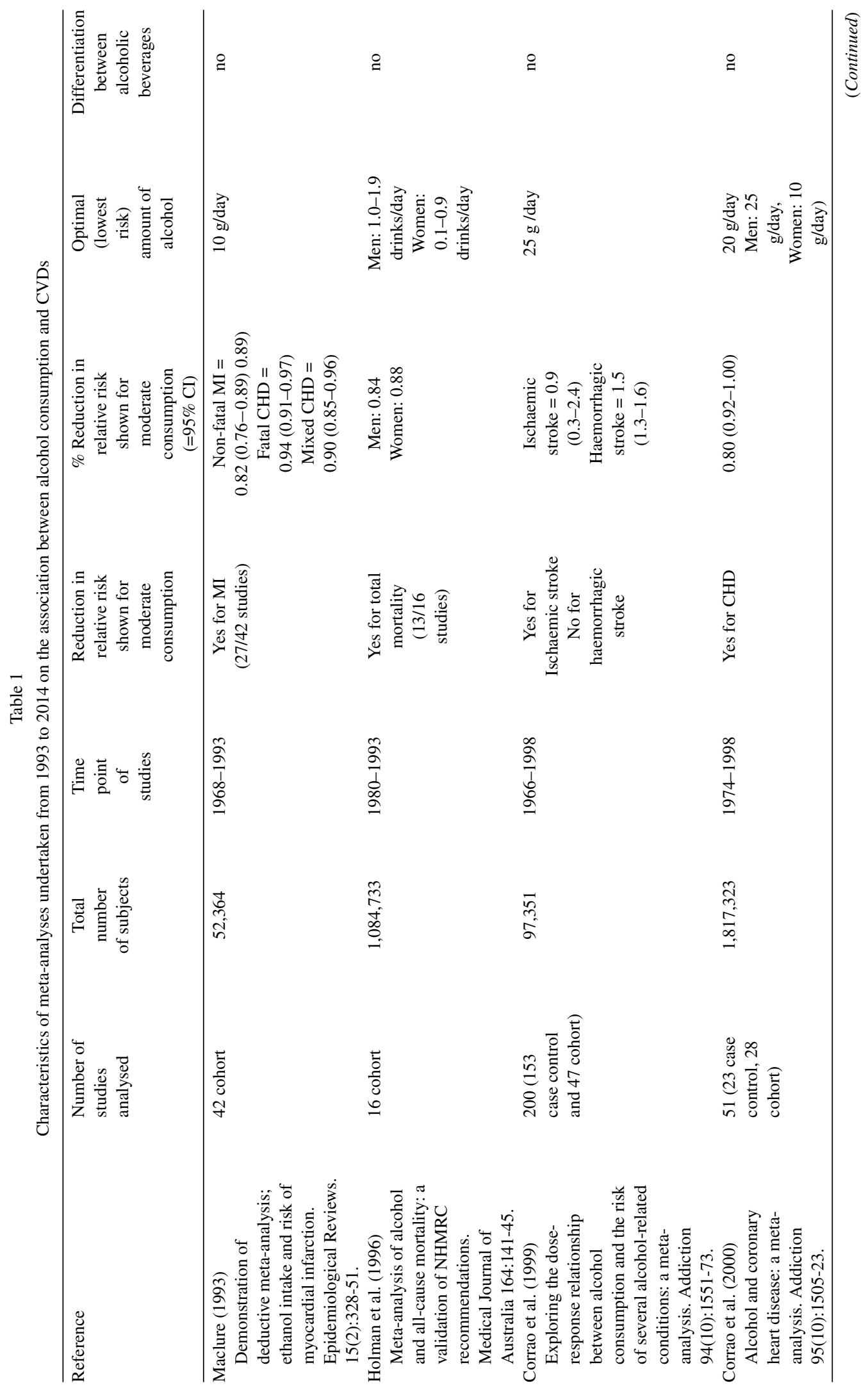




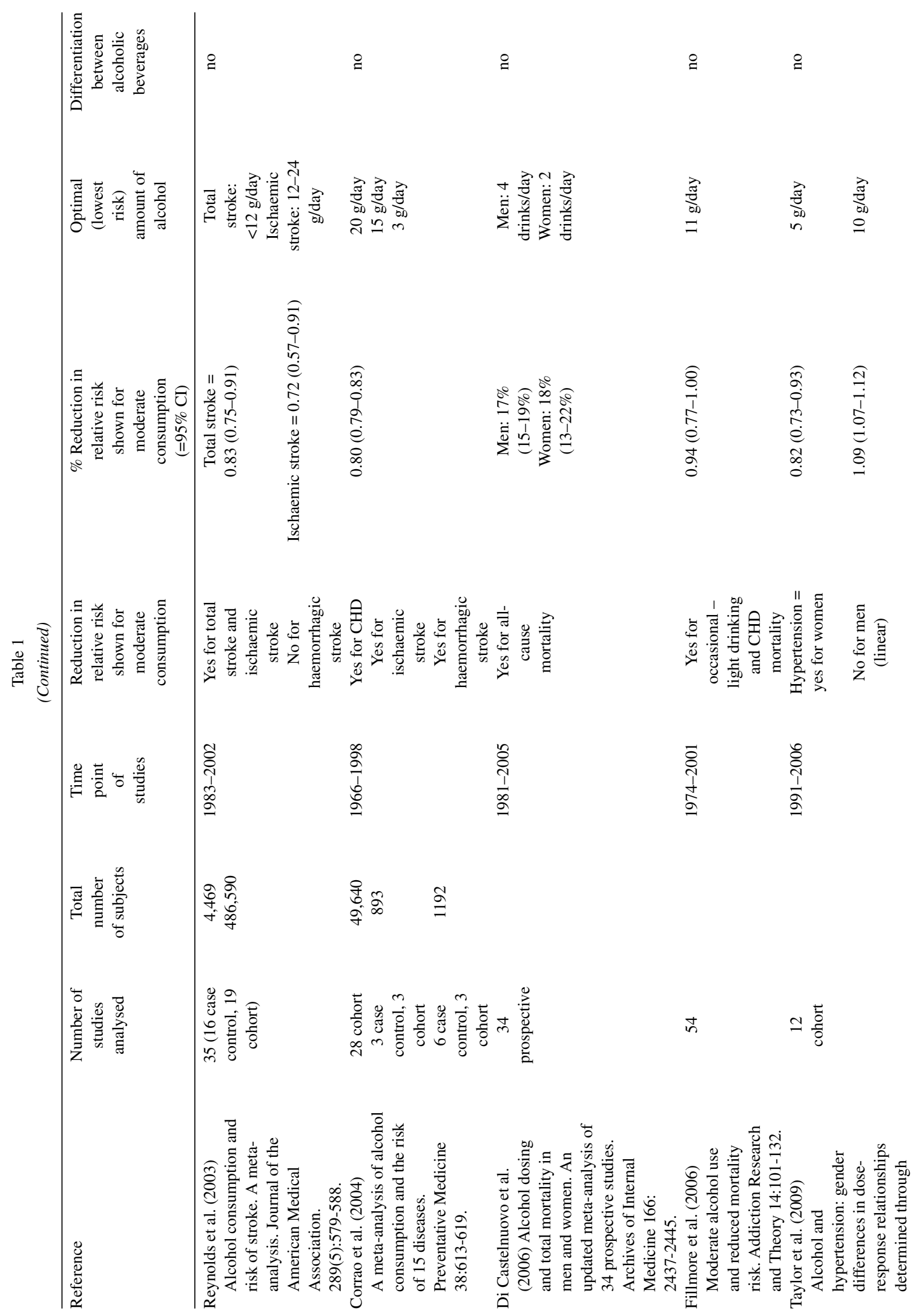




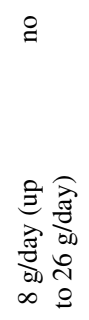

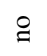

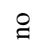

ஓ

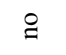

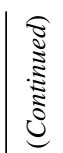

$\begin{array}{ll}0 & 6 \\ 0 & 0 \\ 0 & 0 \\ 0 & 0 \\ 0 & 0 \\ 0 & 0 \\ 0 & 0\end{array}$

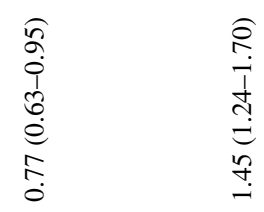
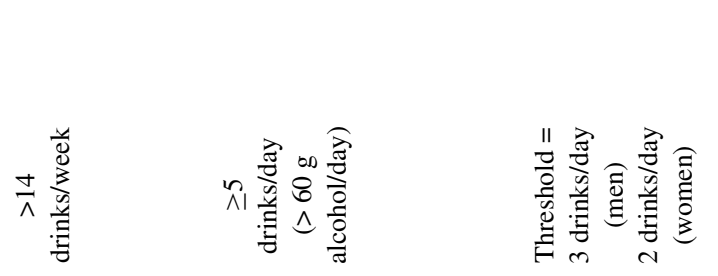

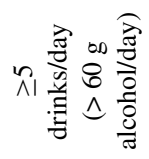

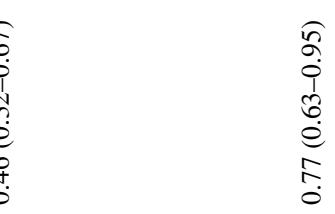

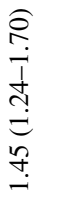

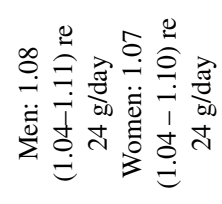

$\begin{array}{ll}8 & 0 \\ 己 & 0 \\ 0 & 0 \\ 0 & 0 \\ 0 & 0\end{array}$

尘

完
总
0
$z$

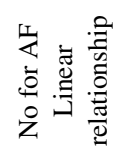

$\infty$
$\stackrel{1}{1}$
$\infty$
$\infty$
0

高

$\stackrel{0}{1}$
1े
$\infty$
2

$\infty$
$\stackrel{1}{1}$
$\frac{1}{\infty}$
0
0

ڤn

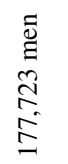

字

$\overline{5}$
5
5

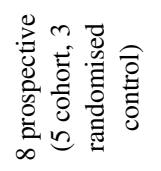

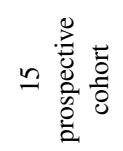

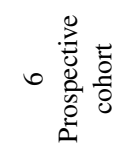

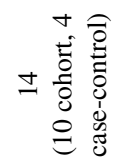

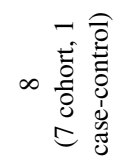

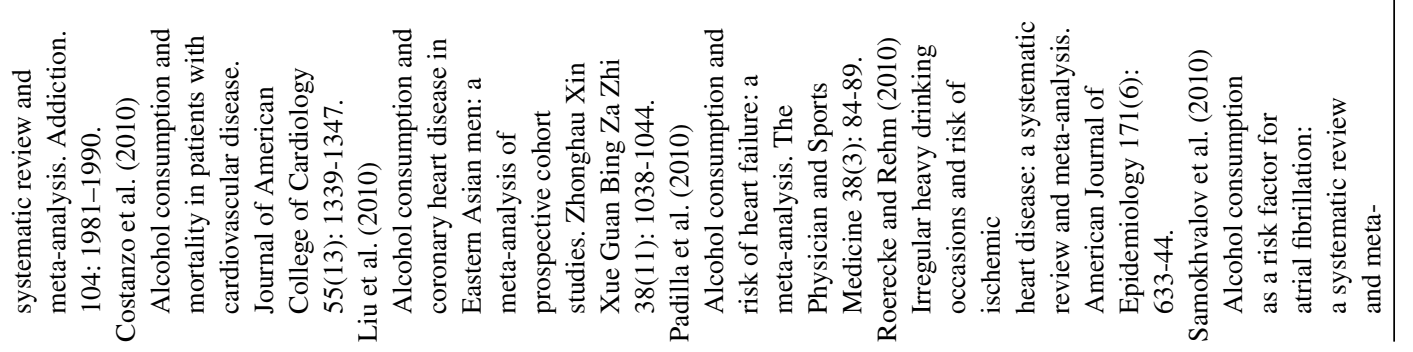




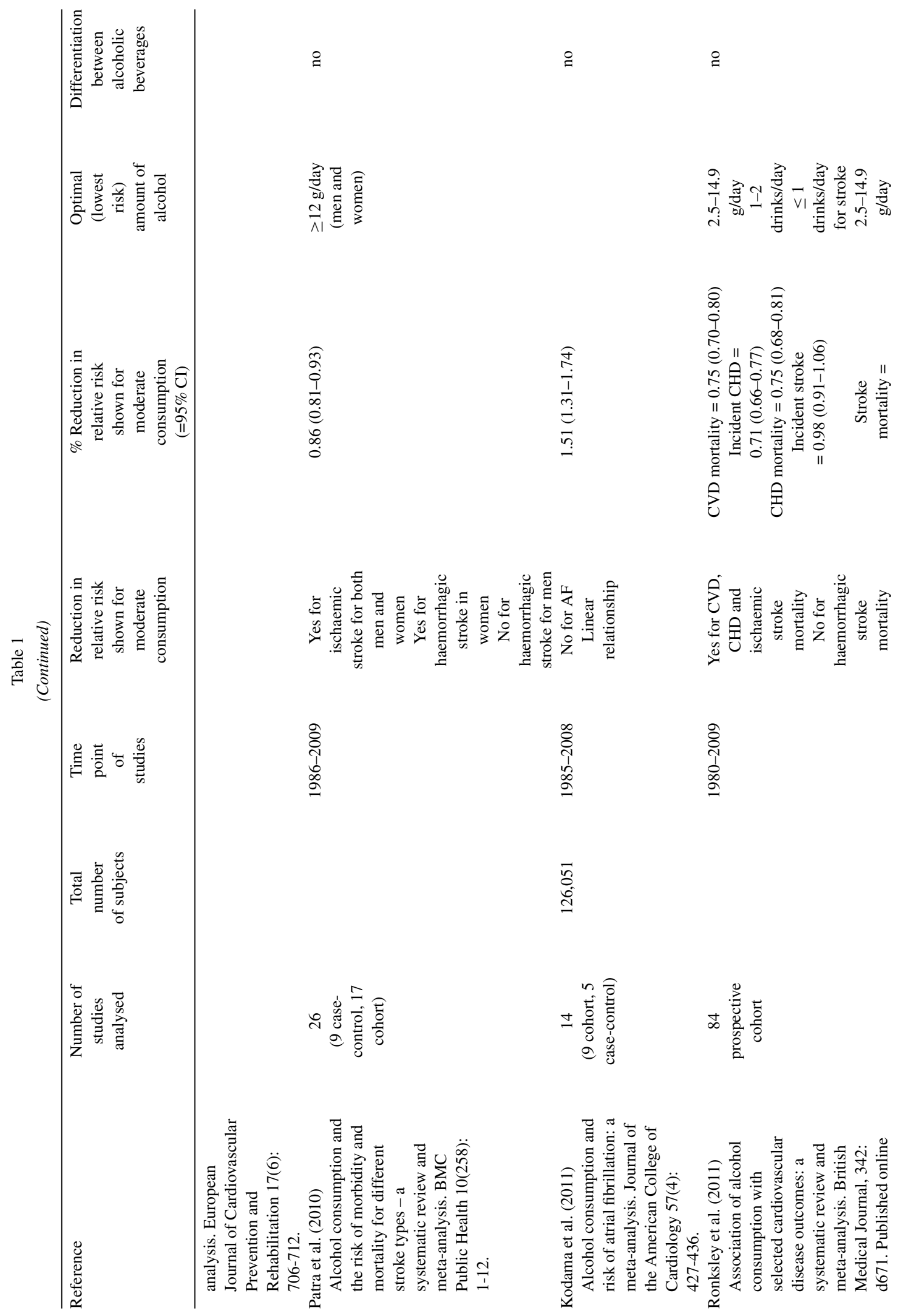




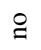

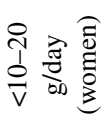

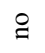

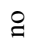

要

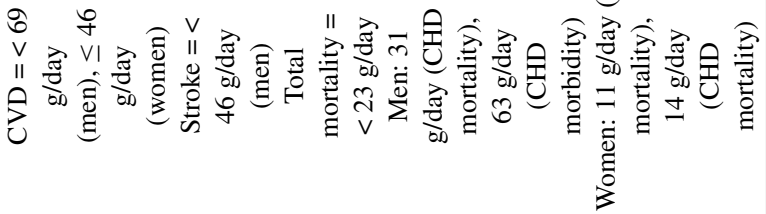

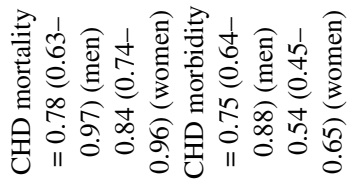

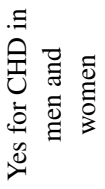

0
$\stackrel{0}{\circ}$
1
$\infty$
$\infty$
0

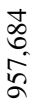

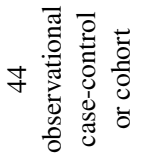

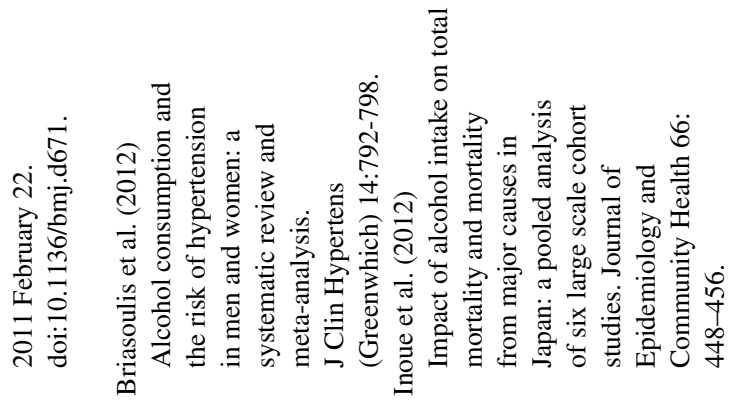

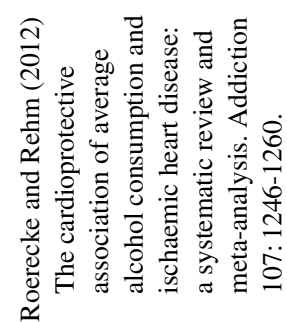


alcohol concentrations than men for the same amount of alcohol consumed [82]. It also reflects that women are more sensitive or susceptible to organ and tissue damage from alcohol than men.

The most comprehensive and relatively recent review of 84 prospective studies undertaken from 1980 to 2009 also used lifetime abstainers as the reference category [83]. Alcohol consumption of 2.5 to $14.9 \mathrm{~g} /$ day was consistently associated with a $14-25 \%$ reduced risk of cardiovascular disease mortality, and specifically the incidence of, and mortality from coronary heart disease and stroke per se. This reduced risk was observed for both men and women for coronary heart disease but the reduction was less for women for stroke, consistent with observations of other meta-analyses. The inclusion of former drinkers did not appear to bias the association of alcohol consumption with cardiovascular disease.

As concluded by Ronksley et al. (2011), the overall association between alcohol consumption and cardiovascular disease and coronary heart disease was actually apparent over 10 years ago, and more recent studies and meta-analyses undertaken have not significantly altered the estimated associations [83].

Concerning all-cause mortality, the 1996 Australian meta-analysis by Holman et al. of 16 cohort studies undertaken between 1980 and 1993, was the first to suggest that the J-shaped relationship between alcohol and CVD could be extended to total or allcause mortality. A $16 \%$ and $12 \%$ reduction in risk of death from all-causes was calculated for men and women, respectively, at 10-19 and 1-9 g alcohol/day.

Ten years later, a larger meta-analysis by $\mathrm{Di}$ Castelnuovo et al. (2006) of 34 studies undertaken between 1980 and 2005 corroborated this initial observation. It suggested that there was now a 17 and $18 \%$ reduced risk for men and women, respectively, which could be extended out to approximately $40 \mathrm{~g} /$ day for men and $20 \mathrm{~g} /$ day for women [49].

From all these studies and meta-analyses (Table 1), it can be estimated that the moderate consumption of an alcoholic beverage such as wine can reduce the relative risk of, and mortality from, cardiovascular diseases by approximately $25-30 \%$, as compared to that of abstention and excessive consumption.

\subsection{Effect of age on the relationship between alcohol consumption and CVD}

The relationship between alcohol consumption and the risk of all-cause mortality appears to be age dependent [85]. A cardioprotective effect is first observed when risk factors for CVD begin to influence medium and long-term health, that is, at approximately age 40 years for men and approximately age 50 years for women $[86,87]$. Accordingly, in women, onset of cardioprotection depends on the age of onset of menopause and use of hormone replacement therapy [36, 42, 49, 84, 88-90].

Furthermore, initiation of moderate alcohol consumption at ages 45-64 years is also associated with an up to $40 \%$ reduction in CVD risk compared to both abstinence and light consumption after approximately four years which was maintained even when other CVD risk factors were considered [91-93].

Cardioprotection generally continues past 65 and 75 years of age [94-97]. Simons et al. (2014), for example, in a population of 2,805 noninstitutionalised subjects aged 60 years and older, observed that at 20 years of follow-up, there is significant protection from CVD for moderate alcohol consumers compared to both abstainers and heavy consumers [97]. In addition, men and women consuming any alcohol survived 12 months longer than their abstinent peers. This relationship did not appear to be impacted or mediated by the CVD risk factors of diabetes, hypertension, obesity or the ratio of LDL to HDL cholesterol.

There is also data that suggests that the consumption of alcohol at a younger age does reduce the risk of CVD at a later age [98-101] by modulating certain biomarkers for CVD.

\subsection{Effect of pre-exisitng CVD on the relationship between alcohol consumption and $C V D$}

While the earlier studies focused on healthy individuals, the J-shaped relationship between CVD risk and alcohol consumption appears conserved among moderate alcohol consumers with pre-existing CVD conditions such as hypertension [102-106]. In individuals with pre-existing hypertension, moderate alcohol consumption has been observed to be inversely associated with CVD events such as MI [107], heart failure [108] and ischaemic stroke [109]. In the 10,530 patient population of the EPIC-NL cohort followed for 9.4 years, the association was specifically seen with wine consumption and not beer or spirits. Similar inverse associations have been observed for angina pectoris and previous revascularization [110]. 
In survivors of an acute myocardial infarction, long-term moderate alcohol consumption is inversely associated with all-cause and cardiovascular mortality among men who survived a first MI [111]. This J-shaped relationship may, however, be strongest among individuals with less impaired cardiac function after MI and should be examined further [112, 113].

The J-shaped relationship between CVD risk and alcohol consumption is also conserved among moderate alcohol consumers with pre-existing cerebrovasular disease, that is, individuals who survived a stroke [114].

\subsection{Relationship between alcohol and individual cardiovascular diseases}

In addition to reducing the risk of atherosclerosisrelated cardiovascular events, such as coronary heart disease and myocardial infarcts, studies have also considered the relationship between alcohol and the specific cardiovascular diseases of atrial fibrillation, heart failure, hypertension and peripheral vascular disease as well as to non-coronary CVD diseases such as stroke [35, 47, 54, 69, 108, 115-120]. Lightto-moderate drinking was observed as generally beneficial in minimising the risk of these cardiovascular events, even after accounting for incident MI, except for atrial fibrillation and hypertension $[121,122]$. Heart failure, for example, is a complex syndrome with multiple causes including coronary heart disease, endomyocardial fibrosis, hypertension, myocardial infarction, obesity and type 2 diabetes $[123,124]$. Accordingly, the relationship between alcohol and the risk of heart failure appears to be a summation of the relationships between alcohol and the risk of the contributing cardiovascular events [47, 81]. From the US Physician's Health Study I (1982 to 2008), moderate alcohol consumption independently and jointly with five other healthy lifestyle habits, reduced the lifetime risk of heart failure [54].

\subsection{Atrial fibrillation}

The relationship between atrial fibrillation, a common chronic cardiac arrhythmia, and alcohol appears to be a casual, linear and dose-response relationship, which may reflect alcohol-induced electrophysiological changes in atrial cells [121, 122, 125-127]. Atrial fibrillation is closely associated with both heart failure and hypertension.

\subsection{Hypertension}

For hypertension, the relationship with alcohol is consistently J-shaped for women, with a maximal cardioprotective effect observed at approximately $5-15 \mathrm{~g} /$ day, while the risk of hypertension increases linearly for men with each drink [128-132]. As only women appear to benefit from light to moderate alcohol consumption, this suggests that the mechanisms underlying the benefit may be different to those for coronary heart disease where both men and women equally benefit from moderate alcohol consumption. Alternatively, differences in the pattern of consumption, beverage choices, diet and lifestyle may account for the gender differences.

\subsection{Stroke}

There are two primary types of stroke, ischaemic and haemorrhagic, and alcohol has a different relationship with the risk of each type. Ischaemic stroke results from the blockage of an intracerebral artery, either through a local blood clot or a distal embolism, which may be a blood clot, a fat globule or a gas bubble in the bloodstream. Its risk factors are atrial fibrillation and hypertension [133]. Consequently, the apparent inverse association of moderate alcohol consumption and risk of ischaemic stroke occurs at a lower amount of alcohol and with a lower magnitude of risk reduction than does the corresponding association with risk of CHD [50, 83, 134-136]. Only a regular pattern of light consumption is consistently associated with a reduced risk of ischaemic stroke $[66,132,138]$. For example, in the Prospective Epidemiological Study of Myocardial Infarction (PRIME), binge drinking approximately doubled the risk of an ischaemic stroke compared with regular consumption [138].

There is consensus among studies that heavy alcohol consumption is always associated with a higher risk of both ischaemic and haemorrhagic strokes. The relationship between moderate alcohol consumption and haemorrhagic stroke is less certain. Some studies have observed a J-shaped relationship while others observed a linear and dose-dependent relationship between the amount of alcohol consumed and the risk of hemorrhagic stroke [41, 139, 140-142]. If J-shaped, the optimal amount of alcohol is even lower than that for ischaemic stroke. For example, while Corrao et al. (2004) calculated a significantly increased risk for ischaemic stroke 
at $100 \mathrm{~g} \mathrm{alcohol/day,} \mathrm{for} \mathrm{haemorrhagic} \mathrm{stroke} \mathrm{this}$ was calculated at $50 \mathrm{~g} /$ day [41]. This difference in risk between stroke types may be associated with an alcohol-induced increase in blood pressure in heavier consumers [139, 143].

These observations may reflect the alcoholinduced reduction in blood clotting which decreases the risk of a blood clotting-related event such as a myocardial infarction and an ischaemic stroke, but increases the risk of bleeding or a haemorrhage in the brain [144].

\subsection{Mechanisms of alcohol in reducing CVD risk}

CVD and atherosclerosis result from an interaction of lipids, haemostasis, inflammatory, endothelial factors and hormonal factors. Accordingly, cholesterol or lipid values, for example, are a biomarker and risk indicator for coronary and vascular diseases. Plasminogen activator inhibitor, tissue plasminogen activator, plasminogen, von Willebrand factors, fibrinogen, thromboxane and e-selectin are biomarkers for haemostasis. C-reactive protein, leukocytes and the pro-inflammatory cytokines, interleukin and tumor necrosis factor- $\alpha$, are biomarkers for inflammation. Intracellular adhesion molecule and vascular cell adhesion molecule are biomarkers for endothelial function as well as inflammation, and adiponectin and leptin are adipocyte hormone biomarkers. These proposed mechanisms of alcohol in reducing CVD are summarised in Table 2.

A meta-analysis of 42 experimental studies, which examined the effects of alcohol consumption on CVD biomarkers, attributed the cardioprotective effect of light-to-moderate alcohol consumption: $60 \%$ of this cardioprotection was attributed to effects on high density lipoprotein, $20-30 \%$ to fibrinogen, $5-10 \%$ to insulin and $0-5 \%$ to other haemostatic factors [145]. The meta-analysis also estimated that $30 \mathrm{~g}$ of alcohol per day would increase the plasma concentration of high density lipoprotein (HDL) by approximately $4 \mathrm{mg} / \mathrm{dL}$ which would be associated with a $17 \%$ reduction in risk of coronary heart disease. It would also decrease the plasma concentration of fibrinogen by approximately $0.075 \mathrm{~g} / \mathrm{L}$, which would be associated with a $12.5 \%$ reduction in risk of coronary heart disease [146]. This translated into an overall $24.7 \%$ reduction in the risk of coronary heart disease from the consumption of $30 \mathrm{~g}$ of alcohol per day. Klatsky and Udaltsova (2007) further translated this into a $10 \%$ reduction in risk of all-cause mortality [42].

\subsection{Lipid effects}

A more recent meta-analysis of 44 experimental studies on 21 biomarkers for CVD calculated that there was a significant dose-response relationship between alcohol consumption and the plasma concentration of HDL, and its primary constituent apolipoprotein A1, which was not significant for the other lipid biomarkers [147]. This was a similar observation to that made by Rimm et al. [148] and Djoussé et al. [149], where HDL was the largest contributor to CVD risk reduction at $28.7 \%$. HDL transports cholesterol from lipid-laden macrophages of atherosclerotic arteries to the liver for secretion into the bile, a process which is referred to as reverse cholesterol transport. Correspondingly, a dose-response relationship has been observed between alcohol consumption and reverse cholesterol consumption where alcohol stimulates the cellular cholesterol efflux and its esterification in plasma which is then incorporated into HDL particles [323]. HDL is also involved in inhibiting oxidation, inflammation, activation of the endothelium, coagulation, and platelet aggregation associated with atherosclerosis leading to coronary heart disease and peripheral artery disease [150]. In addition, HDL inhibits certain changes associated with the oxidative modification of LDL by endothelial and smooth muscle cells [151-153]. An increase in paraoxonase activity also follows an increase in the plasma concentration of HDL which may further protect LDL against oxidation [322]. Therefore, a low plasma concentration of HDL and its constituents is a risk factor for CVD. Studies comparing the effects of beer, wine and spirit consumption on the plasma concentration of lipids observed that they all increased the plasma concentration of HDL [154-156], suggesting that this an alcohol associated cardioprotective biological mechanism. Alcohol appears to increase the plasma concentration of HDL by stimulating the hepatic synthesis and secretion of its subcomponents, apolipoproteins A-I and A-II [157, 158].

\subsection{Haemostasis effects}

Normal haemostasis involves a delicate balance between coagulation and fibrinolysis, that is, lysis of the insoluble fibrin-platelet clot, which is regulated through the synthesis of fibrinolytic proteins. From in vitro and in vivo studies, alcohol has been observed to have two inter-related anti-thrombotic mechanisms involved in decreasing coagulation and increasing 


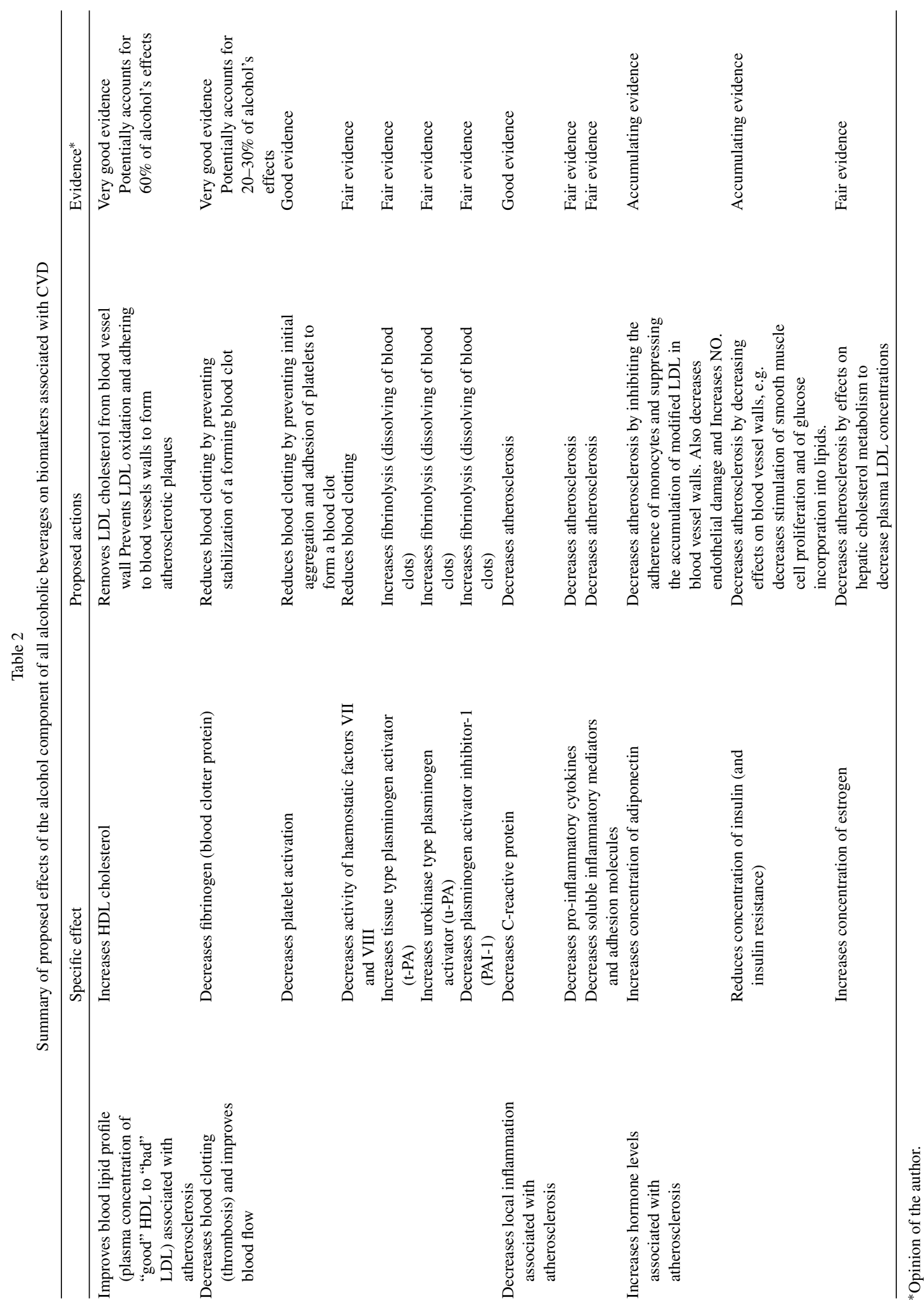


fibrinolysis. Specifically, alcohol decreases the concentration of plasma fibrinogen, decreases platelet aggregation and adhesiveness, and decreases the activity of factor VII and factor VIII associated with coagulation; and changes the concentration of the fibrinolytic proteins, tissue type plasminogen activator (t-PA), urokinase type plasminogen activator (u-PA) and plasminogen activator inhibitor-1 (PAI-1) [159-161]. Although Brien et al. [147] calculated the association between alcohol consumption and the plasma concentration of fibrinogen, which is converted into the fibrin-platelet clot, was calculated to be significant, the association with other haemostasis biomarkers was not significant as insufficient data did not enable meta-analysis. When the contribution of biological mechanisms to CVD risk reduction was calculated by Djoussé et al. [149] combined anti-thrombotic mechanisms countributed $5 \%$ to a reduced risk.

\subsection{Inflammatory effects}

There is increasing evidence that atherosclerosis is actually an inflammatory disease involving numerous cell types, such as macrophages, T-lymphocytes, platelets and endothelial cells, which produce and secrete numerous pro-inflammatory cytokines and growth factors that act locally to promote atherosclerosis [3, 162-164]. Accordingly, alcohol induces anti-inflammatory effects or responses associated with atherosclerosis. The association between alcohol consumption and inflammatory biomarkers was not calculated to be significant by Brien et al. [147]. Small randomised controlled clinical studies, however, as well as an observational study of 483 subjects followed for four years, suggest that moderate alcohol consumption reduces C-reactive protein, and the pro-inflammatory cytokines interleukin- 6 and tissue necrosis factor- $\alpha[158,165,166]$. Supporting the results of initial in vitro studies [167], a down-regulation and hence reduction in the plasma concentration of the soluble inflammatory mediators CD40 ligand, IL-16, monocyte chemotactic protein (MCP)-1, vascular cell adhesion molecule (VCAM)1 and E-selectin has also been recently observed in high-CVD-risk subjects following $30 \mathrm{~g}$ of alcohol/day [168].

\subsection{Hormonal effects}

While Brien et al. [147] observed no association between alcohol consumption and inflammatory biomarkers, they did, however, calculate that there was a significant association with adiponectin. Adiponectin is an adipocyte hormone related to a reduced risk of coronary heart disease and diabetes. Insufficient data did not enable further meta-analysis for other hormonal biomarkers including insulin, or for endothelial biomarkers [147].

\subsection{Optimal amount of alcohol}

From Table 3, the optimal or most cardioprotective amount of alcohol was up to $15 \mathrm{~g}$ alcohol/day for women and up to $30 \mathrm{~g}$ alcohol/day for men, which is consistent with that determined by Rimm et al. [145]. These calculations suggest that alcohol reduces the risk of CVD by reverse cholesterol transport, haemostasis and insulin sensitivity mechanisms. In a clinical context, the alcohol-induced changes in HDL, fibrinogen and adiponectin are pharmacologically relevant and comparable if not greater than that induced by traditional US Food and Drug Administration-approved drug therapy [147].

In contrast to moderate alcohol consumption [169], heavy alcohol consumption is an established risk factor for hypertension and the development and progression of atherosclerosis, and is associated with lower fibrinolyic activity, pro-coagulation events, and higher blood viscosity. Alcohol-induced oxidative stress (production of reaction oxygen species), accumulation of fatty acid ethyl esters, modification of lipoproteins, and increased expression of pro-inflammatory cytokines and vascular cellular adhesion molecules, all contribute to and promote the formation of atherosclerotic plaques [170]. In addition, the alcohol-induced increase in blood pressure may counteract direct atheroprotective mechanisms. Recently, in vitro models of atherosclerosis, have shown that the primary breakdown product of alcohol, acetaldehyde, may also affect pro-inflammatory cytokines and vascular cellular adhesion molecules [171].

In summary, there is extensive evidence for plausible biological mechanisms for protection against coronary heart disease by low to moderate alcohol consumption which adds credence to a causal relationship. These mechanisms include the effects of alcohol via improved lipid factors, improved haemostatic factors, improved endothelial function, and a lower risk of diabetes mellitus [172, 173]. As concluded by Brien et al. [147], it was stated that: "Favourable changes in several cardiovascular 
Table 3

Characteristics of 3 meta-analyses undertaken from 1999 to 2011 on the association between wine consumption and CVDs

\begin{tabular}{|c|c|c|c|c|c|c|c|c|}
\hline Reference & $\begin{array}{c}\text { Number } \\
\text { of studies } \\
\text { analysed }\end{array}$ & $\begin{array}{c}\text { Total } \\
\text { number } \\
\text { of } \\
\text { subjects }\end{array}$ & $\begin{array}{l}\text { Time } \\
\text { point } \\
\text { of } \\
\text { studies }\end{array}$ & $\begin{array}{l}\text { Reduction in } \\
\text { relative risk } \\
\text { shown for } \\
\text { moderate wine } \\
\text { consumption }\end{array}$ & $\begin{array}{l}\% \text { Reduction } \\
\text { in relative risk } \\
\text { shown for } \\
\text { moderate } \\
\text { wine } \\
\text { consumption } \\
(=95 \% \mathrm{CI})\end{array}$ & $\begin{array}{l}\text { Optimal } \\
\text { (lowest } \\
\text { risk) } \\
\text { amount of } \\
\text { wine }\end{array}$ & $\begin{array}{l}\text { Differentiation } \\
\text { between } \\
\text { alcoholic } \\
\text { f beverages }\end{array}$ & $\begin{array}{l}\text { Difference } \\
\text { observed } \\
\text { between beer, } \\
\text { wine and } \\
\text { spirits }\end{array}$ \\
\hline $\begin{array}{l}\text { Cleophas (1999) } \\
\text { Wine, beer and spirits and the } \\
\text { risk of myocardial } \\
\text { infarction: a systematic } \\
\text { review. Biomed. } \\
\text { Pharmacother. 53: } \\
\text { 417-23. }\end{array}$ & $\begin{array}{l}12 \text { cohort } \\
\text { and } 2 \\
\text { case-control } \\
\text { for MI }\end{array}$ & & 1980-1995 & Yes for MI & $\mathrm{MI} \sim 55 \%$ & $\begin{array}{l}10-40 \\
\text { g/day }\end{array}$ & Yes & $\begin{array}{l}\text { Yes } \\
\text { MI risk is less } \\
\text { for wine than } \\
\text { for beer or } \\
\text { spirits }\end{array}$ \\
\hline $\begin{array}{l}\text { Di Castelnuovo et al. } \\
\text { (2002) Meta-analysis of } \\
\text { wine and beer } \\
\text { consumption in relation } \\
\text { to vascular risk. } \\
\text { Circulation 105: } \\
2836-44 \text {. }\end{array}$ & 13 & 209,418 & 1977-2001 & Yes for CVD & $\begin{array}{c}\text { CVD }=0.68 \\
(0.59-0.77)\end{array}$ & $\begin{array}{c}150 \\
\mathrm{~mL} / \text { day }\end{array}$ & Yes & $\begin{array}{l}\text { Yes } \\
\text { CVD risk is less } \\
\text { for wine than } \\
\text { for beer } \\
(-0.78 \%)\end{array}$ \\
\hline $\begin{array}{l}\text { Costanzo et al. (2011) } \\
\text { Wine, beer or spirit } \\
\text { drinking in relation to } \\
\text { fatal and non-fatal } \\
\text { cardiovascular events: a } \\
\text { meta-analysis. } \\
\text { European Journal of } \\
\text { Epidemiology 26: } \\
833-50 .\end{array}$ & $\begin{array}{c}16 \\
11 \text { cohort } \\
\text { and } 5 \\
\text { case-control }\end{array}$ & $\begin{array}{l}293,917 \\
1\end{array}$ & 1977-2009 & Yes for CVD & $\begin{array}{c}\text { CVD }=31 \% \\
(19-24 \%)\end{array}$ & $21 \mathrm{~g} /$ day & Yes & $\begin{array}{l}\text { Yes } \\
\text { CVD risk was } \\
\text { similar for } \\
\text { wine and for } \\
\text { beer but there } \\
\text { was no } \\
\text { reduced risk } \\
\text { for spirits }\end{array}$ \\
\hline
\end{tabular}

biomarkers (higher levels of high density lipoprotein cholesterol and adiponectin, and lower concentration of fibrinogen) provide indirect pathophysiological support for a protective effect of moderate alcohol use on coronary heart disease."

\section{Reduction of CVD risk related to wine consumption - Is wine different to other alcoholic beverages?}

Wine is an alcoholic beverage. The most abundant alcohol in wine is ethyl alcohol or ethanol, where the concentration of ethanol in 'table' wine generally ranges between 8 and 15\% v/v (Day et al. 2002).

Of the available published literature identified in the undertaken review, the majority does not differentiate between wine, beer and spirits. St Leger et al. [22] published the first ecological ${ }^{1}$ analysis showing a

\footnotetext{
${ }^{1}$ Ecological analyses examine relationships between exposure and outcome with population-level rather than individual-level data.
}

strong inverse association between average per capita consumption of wine and mortality from coronary heart disease. An inverse association was observed for wine in both men and women, which was less strong for spirits and non-existent for beer. Renaud and de Lorgeril [144] in their assessment of the MONICA project ${ }^{2}$ attributed the French reduction in risk of coronary heart disease to their regular moderate consumption of wine and via haemostatic mechanisms. Their subsequent study of 36,360 French men observed that while both moderate wine and beer consumption was associated with a reduced risk of CVD, the association was greater for wine than for beer. Grønbaek et al. [175] in the Copenhagen City Heart Study also observed that the association with CVD and cerebrovascular disease was greater for wine than for beer, and was non-existent for spirits.

Prospective population studies, however, have provided no consensus that wine is more protective than beer or spirits against CVD. For example, Muka-

\footnotetext{
${ }^{2}$ Worldwide monitoring system for cardiovascular diseases organised by the World Health Organisation (1989).
} 
mal et al. [176, 177] found that all beverages were equally protective against MI but that only wine was protective against ischemic stroke in the US Health Professionals Follow-up Study. The first systematic review of ecological, case-control, and cohort studies in which specific associations were available for beer, wine and spirits consumption and risk of coronary heart disease was undertaken in 1996. It concluded that all the alcoholic beverages were cardioprotective [148]. Cardioprotection was also most associated with the common alcohol component.

\subsection{Meta-analyses}

Through a systematic search of the electronic database PUBMED from January 1980 up to May 2014, only three published papers of meta-analyses on the relationship between wine, beer and spirits and risk of CVD were identified (see Table 3 ).

From the analysis of 12 cohort studies from 1980 to 1995, including that of Grønbaek et al. [175], encompassing 284,416 subjects, Cleophas [178] calculated that consumption of one to four drinks/day of beer, wine or spirits was associated with a reduced risk of MI, although the level of significance was greatest for wine. Di Castelnuovo et al. [179] calculated from five cohort and eight case control studies involving 209,418 subjects, that the percentage reduction in risk from up to $150 \mathrm{~mL}$ wine/day was $32 \%$. A similar but smaller association was seen with beer from 15 studies involving 208,036 subjects.

The most recent meta-analysis by Constanzo et al. [75] of 16 studies involving 306,370 subjects, calculated that the percentage reduction in risk of CVD for wine was $31 \%$, where the optimal amount associated with this reduction was $21 \mathrm{~g}$ alcohol/day. A similar association was seen with beer from 13 studies but no association was seen for spirits.

One cohort study not considered in any of these three meta-analyses, however, was that conducted by Klatsky et al. [180], in which 128,934 Northern California adults were followed for approximately 20 years. Lifetime abstainers were the reference group. Frequency of wine consumption was associated with a lower risk for mortality, primarily related to a reduced risk of coronary heart disease than beer and spirit consumption. Similar risk reductions were associated with red, white and other types of wine. The observed percentage reduction in risk for coronary heart disease was $6 \%$ for consuming wine less than once per week, $14 \%$ for two to three days per week, $23 \%$ for four to five days per week and $33 \%$ for approximately daily wine consumption. The reduced risk of death for wine consumers was irrespective of age, cigarette smoking and education. Furthermore, one to two drinks/day of wine was observed to reduce the risk of CHD mortality by $60 \%$ whereas beer consumption only reduced the risk by $30 \%$ and spirit consumption did not reduce the risk at all. Klatsky et al. [180] concluded that since consumption pattern probably has a role in health effects, the usual pattern of ingesting wine slowly with food may be important [148, 181-183]. Such a pattern would attenuate a detrimental high blood alcohol concentration and prolong any beneficial effects on cells, organs and tissues.

Although evidence that protective mechanisms are related to the common alcohol component does not support the hypothesis that wine is most cardioprotective, the consistency and strength of the Klatsky et al. [180] data showing an apparent additional benefit from wine, raises the likelihood of a causal association caused by other components. Components of wine that might confer an additional cardioprotection are phenolic compounds. A comparison of potential effects of beer, wine and spirits on different biomarkers for CVD is shown in Table 4.

\subsection{Role of phenolic compounds in CVD risk}

In addition to alcohols, wine also typically contains a high concentration of phenolic compounds and their polymeric forms compared to other alcoholic beverages. Wine-derived phenolic compounds include the non-flavonoid classes of compounds such as the hydroxycinnamates, hydroxybenzoates and the stilbenes; and the flavonoid classes of compounds such as flavan-3-ols, flavonols and anthocyanins. While polymeric condensed tannins and pigmented tannins constitute the majority of red wine phenolic compounds, their large size precludes absorption and they are thus unlikely to directly contribute to any beneficial biological mechanisms for human health [184]. The total amount of phenolic compounds in a $100 \mathrm{~mL}$ glass of red wine is approximately $200 \mathrm{mg}$ versus $40 \mathrm{mg}$ in a glass of white wine [184-187].

While both wine and beer contain phenolic compounds, the concentration in wine is much greater than that in beer [188]. The types of phenolic compounds found in beer are also different, with different biological activities, to those found in wine. The wine-derived phenolic compounds, that are also present in the fruit and vegetable components of a 
Table 4

Comparison of effects of beer, wine and spirits on different CVD biomarkers/factors (adapted from Chivas-Blanch et al. 2013) [147]

\begin{tabular}{lccc}
\hline & \multicolumn{3}{c}{ Alcoholic beverage } \\
\cline { 2 - 4 } & Wine & Beer & Spirits \\
\hline Endpoints & & & \\
CVD mortality & ++ & + & + \\
All-cause mortality & ++ & + & + \\
MI & ++ & + & \pm \\
Risk factors & & & \\
Blood pressure & & & \\
$\quad$ Anti-hypertensive effect & \pm & \pm & \pm \\
Lipid profile & & & \\
$\quad$ HDL-cholesterol & ++ & ++ & ++ \\
$\quad$ Apolipoprotein-AI, AII & ++ & \pm & \pm \\
Paraoxonase & + & + & + \\
$\quad$ LDL-cholesterol & \pm & \pm & \pm \\
Triglycerides & \pm & \pm & \pm \\
$\quad$ Lipoprotein(a) & + & \pm & \pm \\
Haemostasis & & & \\
$\quad$ Platelet aggregation & + & + & + \\
$\quad$ Coagulation & + & + & + \\
$\quad$ Fibrinogen & ++ & ++ & ++ \\
Endothelial function & & & \\
$\quad$ Nitric oxide & ++ & \pm & \pm \\
FMD dilation & ++ & + & + \\
Insulin sensitivity & ++ & + & + \\
Mechanisms & & & + \\
Oxidative stress & ++ & + & + \\
Inflammation & ++ & + & + \\
\hline
\end{tabular}

++: higher protective effect; +: protective effect; -: negative effect and \pm : not clear or no effect.

Mediterranean-style diet, have also been associated with a reduced risk of CVD [189-192] In the PREDIMED (Prevención con Dieta Mediterránea) study, the class observed to be strongest associated with a reduced risk of CVD is the flavanol class which includes catechin, epicatechin gallate, epigallocatechin, epigallocatechin gallate and proanthocyanidins [191]. A primary source (32\%) of flavanols in the daily diet is wine.

\subsection{Mediterranean diet and lifestyle}

Diet is also a significant source of variation in CVD risk and is accordingly a risk factor that can be readily modified to reduce CVD risk, as well as the impact of other important cardiovascular risk factors [193-197]. A systematic review of the evidence supporting a causal association between dietary factors and CHD ranked a traditional Mediterranean diet as the most likely dietary model to provide protection against CHD [198]. From a 30-year follow-up study in seven countries, the risk of CVD was at least two- to three-fold lower in countries consuming a Mediterranean-style diet compared to that in northern Europe and USA where the diet was generally higher in fat [199]. The core components of a Mediterraneanstyle diet include the high consumption of cereals, fruits, legumes, vegetables and wine, which typically contain a high concentration of phenolic compounds, have previously been associated with a reduced risk of cardiovascular disease [189, 191, 200-205]. For example, subjects placed on a Mediterranean-style diet for 46 months had a $50-70 \%$ lower risk of recurrent cardiovascular disease, compared to control subjects on a higher fat diet [201]. Furthermore, 55\% of patients with metabolic syndrome (high blood pressure, a high cholesterol concentration and a high body mass index) who followed a Mediterraneanstyle diet for two years were symptom-less and had a reduced risk of cardiovascular disease at follow-up compared with only $14 \%$ of patients in the control group [4]. Introducing a Mediterranean-style diet into a non-Mediterranean US population group that included moderate wine consumption with meals was also associated with a reduced CVD risk in the population group after five years [206].

Relatively recent studies have indicated that consumers of wine have a reduced risk of CVD and all cause mortality, similar but additive to that for consumers of a traditional Mediterranean diet [55, 83, 207-209]. This is exemplified in an epidemiological study assessing the geographical distribution of cardiovascular disease in Spain, one of the 18 Mediterranean countries. A higher rate of cardiovascular disease was observed in those Spanish regions with the lowest per capita wine consumption, despite having, overall, a Mediterranean-style diet. The rate of CVD was, however, still less than that of countries consuming a higher fat and lower phenolic compound diet [210]. In addition, results of recent cohort studies have confirmed that, among patients with established coronary heart disease or at high-risk of this disease, moderate wine consumption is associated with lower incidence of cardiovascular events and total mortality as compared with abstainers $[95,138,211,212]$.

\subsection{Confounding factors}

Klatsky et al. (2003) mused whether the reduced risk of CVD of wine compared with beer and spirit consumption was partially related to the drinking pattern and associated traits of the consumers [180]. Wine consumers were considered to generally have 
'healthier' traits, such as a healthier diet and lifestyle, and healthier amount and pattern of consumption [213-217].

An additional effect of adding red wine to a Mediterranean-style diet on the concentration of plasma lipids has been recently demonstrated. The inclusion of 10 to $20 \mathrm{~g}$ alcohol/day as wine was observed to reduce the ratio of low density lipoprotein to high density lipoprotein by $13 \%$, independent of, and compared to regular physical exercise and/or a healthy Mediterranean-style diet [218]. If there is an excess of low density lipoprotein to high density lipoprotein, risk of atherosclerosis increases. This was also observed in addition to traditional statin drug therapy.

The US Alternative Healthy Eating Index 2010 (AHEI2010), a Mediterranean-style diet was comprised of 11 core components, including alcohol consumption of approximately $10 \mathrm{~g} /$ day. When alcoholic beverages such as wine were excluded from the diet, the cardioprotective effect of the diet was reduced by $10 \%$, from $29 \%$ to $19 \%$ [219]. This observation supports that moderate wine consumption is an important synergistic as well as independent contributor to the cardioprotective diet. While statin drug therapy similarly reduces the risk of CVD by approximately $30 \%$, it is also associated with adverse effects and is expensive [220].

Furthermore, while both wine and spirit consumption with food have been associated with a reduced risk of CVD compared with lifetime abstinence, only an inverse association between wine and CVD mortality has also been observed independent of consumption pattern [221].

\subsection{Mechanisms of phenolic compounds in reducing $C V D$ risk}

Similar to the alcohol component of wine, winederived phenolic compounds exert multiple effects on the cardiovascular system. These include effects on plasma lipids, haemostatic effects on blood pressure and blood flow, anti-inflammatory effects and effects to enhance endothelial function; the latter is specific to phenolic compounds. As wine contains both alcohol and phenolic compounds, studies have often compared the effects of red wine and de-alcoholised red wine and an alcoholic beverage with not containing phenolic compounds on biological markers for CVD. The results of human clinical studies have been supplemented by in vitro, ex vivo and animal studies.

\subsection{Effects on lipids}

In contrast to the alcohol content of wine, winederived phenolic compounds do not affect the plasma concentration of HDL. A high plasma concentration of oxidatively modified low density lipoprotein (LDL) is also a risk factor for CVD, where oxidizedLDL initiates and aids all stages of the atherosclerotic process $[153,222]$. The cholesterol that accumulates in atherosclerotic lesions originates primarily from LDL. Oxidized-LDL can also stimulate platelet activation associated with coaggulation, and the activated platelets in turn can increase the susceptibility of LDL to oxidation [223].

Initial in vitro studies suggested that wine-derived phenolic compounds had predominantly lipid lowering effects, increasing the anti-oxidant capacity of plasma thereby protecting LDL against oxidation by circulating free radicals [187, 224-226]. Like other plasma anti-oxidants, the wine-derived phenolic compounds actually bind to the LDL particle by forming a glycoside bond, which protects it from oxidation [227]. The results of in vitro studies have not necessarily been supported by subsequent in vivo and ex vivo studies [226, 228-234]. The meta-analysis undertaken by Brien et al. (2011) consequently observed no change in the plasma concentration of low density lipoprotein after consumption of any alcoholic beverage [147]. However, in context with in vitro studies that have demonstrated that the winederived phenolic compounds are anti-oxidative in plasma, it is also possible that as alcohol itself is a pro-oxidant, the potentially anti-oxidative winederived phenolic compounds may merely counter the pro-oxidative alcohol concomitantly absorbed [234-236].

The plasma concentration of lipoprotein (a), another, although independent, lipid risk factor for atherosclerosis and CVD, however, may be reduced by wine-derived phenolic compounds. Estruch et al. (2011) and Chiva-Blanch et al. (2013) both observed a decrease in the concentration of lipoprotein (a) after $30 \mathrm{~g}$ alcohol/day as red wine for four weeks in healthy individuals and those at increased risk of CVD [174, 234].

\subsection{Haemostasis}

Similar to the alcohol component of wine, wine-derived phenolic compounds can modulate haemostasis [2]. There is in vitro evidence that 
wine-derived phenolic compounds independently and additively reduce platelet aggregation [237-240], but the different flavonoid classes may exhibit different effects, particularly on arachidonic acid metabolism [241]. Specifically, wine-derived phenolic compounds have been observed to down-regulate cellular adhesion processes, which are responsible for the recruitment and activation of platelets and their aggregation at the site of vascular damage, hence reducing platelet aggregation [242].

Although it is difficult to distinguish between the effects of the alcohol and those of the phenolic components of wine in an in vivo study, several animal studies have demonstrated a difference between alcohol and wine-derived phenolic compounds on platelet aggregation [243-247]. Red wine and dealcoholised red wine, for example, consistently inhibited platelet aggregation at a significantly lower blood alcohol concentration than did an alcohol solution. Platelet aggregability has been observed to be dependent on the amount and pattern of alcohol consumption, such that binge patterns and heavy consumption have been observed to be associated with platelet rebound effects or hyperaggregability, which are implicated in sudden deaths after episodes of excessively heavy consumption and in alcoholics [248]. The type of beverage consumed may also affect platelet aggregability. For example, in contrast to spirits, irrespective of amount consumed, wine does not appear to be associated with platelet rebound effects [249]. This suppression of hyperaggregatability has been attributed to the inhibition of alcohol-induced lipid peroxidation by wine-derived phenolic compounds [238, 248, 250].

The consumption of both red and white wine has also been observed to increase fibrinolytic acitivity [251, 252], and wine-derived phenolic compounds have been observed to increase fibrinolytic activity independent of alcohol. For example, phenolic compounds such as catechin, epicatechin, quercetin, and resveratrol have also been observed to upregulate both t-PA and u-PA gene transcription, which results in the sustained increased expression of surfacelocalized fibrinolytic activity in cultured human umbilical vein endothelial cells [253].

\subsection{Endothelial function}

Another purported biological mechanism of winederived phenolic compounds is restoration of endothelial function. Dysfunctional endothelium is an early marker of atherosclerosis and actively contributes to the development of atherosclerotic plaques by, for example, inducing the proliferation of monocyte-derived macrophages that ingest oxidizedLDL to form foam cells, and also contributes to the development of blood clots [254]. Endothelial dysfunction may be induced by a high plasma concentration of lipid peroxides and oxidised lipids [255]. The synthesis of nitric oxide (NO) within endothelial cells plays a pivotal role in modulating homeostasis and preventing the initiation and progression of atherosclerosis [256]. One of the main effects of NO is vasodilation by reducing the contractility of vascular smooth muscle cells in the media layer of the vessel wall. Impaired NO synthesis is a feature of both atherosclerosis and endothelial dysfunction.

Supplementation of a high-fat diet with red wine has been observed to reverse or prevent endothelial dysfunction in several parallel-design studies [257, 258]. Several, but not all, cross-over design studies also observed that red wine or dealcoholised red wine improved endothelial function [259-266] and blood flow [267]. Red grape juice, red wine and dealcoholised red wine have all been observed in animal studies [268, 269], in vitro [270] and in vivo [271] to relax vascular endothelial smooth muscle. The synthesis and release of NO from endothelial cells is induced by inducing or up-regulating NO synthase gene expression (eNOS) [269, 272]. This effect appears independent of the ability of grape- and winederived phenolic compounds to protect against lipid oxidation.

In addition, the induced synthesis of NO by winederived phenolic compounds has other protective effects on both the early and late phases of the formation of the formation of atherosclerotic lipid plaques in the blood vessel wall (atherogenesis). For example, $\mathrm{NO}$ also inhibits platelet aggregation and platelet adhesion to the endothelium or lining of the blood vessel wall, preventing the formation of blood clots [273]. NO also controls the expression of genes involved in atherogenesis, such as the chemoattractant protein MCP-1, surface adhesion molecules CD11/CD18, P-selectin, vascular molecule-1 and intercellular adhesion molecule-1, thereby preventing leukocyte adhesion to the vascular endothelium and leukocyte migration into the blood vessel wall [274-276].

Endothelium dysfunction is also prevented by endothelin-1 (ET-1) antagonists; ET-1 is a potent vasoconstrictor peptide and its overproduction is another risk factor for atherosclerosis [277]. Wine- 
derived phenolic compounds such as resveratrol have been observed in vitro to inhibit the synthesis of ET-1 by suppressing transcription of the prepro-ET-1 gene and by changing the morphology of the endothelial cell to modify tyrosine-kinase signalling and hence tyrosine phosphorylation [277, 278]. Inhibition is, however, dose dependent.

\subsection{Anti-inflammatory effects}

In addition to the anti-oxidant effects of moderate wine consumption which affect atherosclerosis, there are specific inflammatory biomarkers of cell adhesion which are also modulated by wine-derived phenolic compounds. Cell adhesion molecules and cytokines participate in the recruitment of circulating leukocytes to the vascular endothelium and sub-endothelial spaces involved in initiating atherosclerosis. Plasma concentrations of vascular cell adhesion molecule -1 (VCAM-1) and intercellular CAM-1 (ICAM-1) have been observed to be significantly decreased by wine-derived phenolic compounds in some initial human in vivo studies $[168,279]$. These may be indirectly modulated via effects on NO. Wine-derived phenolic compounds have also been observed to decrease the plasma concentration of C-reactive protein $[279,280]$, as have the inflammatory biomarkers, interleukin-1a (IL-1a), very late antigen-4 (VLA4) lymphocyte expression and lymphocyte function associated antigen-1 (LFA-1) and macrophage- 1 antigen (mac-1). These effects may be dose-dependent.

\subsection{Other effects}

In addition to the lipid, haemostatic, endothelium and anti-inflammatory effects, wine-derived phenolic compounds may also exhibit a cardioprotective effect by inhibiting the induced growth of vascular smooth muscle cells (VSMC) by angiotensin II. Angiotensin II is the main peptide hormone in the reninangiotensin system. In addition to regulating blood pressure and circulating volume [281], angiotension II also induces the growth of VSMC by stimulating the $\mathrm{G}$ protein-coupled angiotensin type $1\left(\mathrm{AT}_{1}\right)$ receptor in VSMC, which activates multiple protein kinase pathway leading to VSMC protein synthesis. On vascular injury, the induced VSMC migrate, which may result in a ruptured atherosclerotic plaque and myocardial infarction. Thus an increased plasma concentration of angiotensin II is considered to contribute to the development of diseases characterised by VSMC growth, such hypertension and atherosclerosis after vascular injury [282].

In vitro, several phenolic compounds appear to inhibit or suppress the angiotensin II-induced growth of VSMC. For example, both quercetin and resveratrol have independently been observed to intefere with the multiple protein kinase pathways and VSMC protein synthesis activated by angiotensin II [283]. In addition, both phenolic compounds have been observed to inhibit the angiotensin-converting enzyme (ACE), which converts angiotensin I to angiotensin II, and thus they may also decrease the plasma concentration of angiotensin II [284] and thereby inhibit the VSMC hypertrophy.

\subsection{Specific compounds}

Considering all the potential cardioprotective mechanisms postulated for wine-derived phenolic compounds, the effect of an alcoholic beverage on lipid oxidation and coagulation and fibrinolysis in vivo may depend on the balance between the pro-oxidant effects of the ethanol component and the concentration of phenolic antioxidant compounds in the beverage, as well as the diet of the consumer. It is also likely that the overall haemostatic effects purportedly associated with moderate wine consumption are attributable to the combined, additive, or perhaps synergistic effects of the ethanol component and the wine-derived phenolic compounds (Fig. 2). Although there are numerous classes of phenolic compounds, catechin, quercetin and resveratrol represent some of the candidates amongst the potentially bioactive phenolic compounds in wine [184].

To have any direct effects on lipids or on haemostasis, for example, the ingested wine-derived phenolic compounds and/or their active metabolites have to be absorbed into the blood stream, although not for direct effects on the small and large intestine. In vivo data have shown that small wine-derived phenolic compounds are absorbed into the blood stream in measurable quantity [224, 225, 229, 231, 257, 286, 295]. Catechin, quercetin, and resveratrol, administered either as single or multiple doses, have been subequently shown to exert significant beneficial effects on established biological markers of CVD risk. These biological markers include endothelial function [272, 287-291] and blood pressure [292-295], as well as more broadly on haemostatic blood clotting and flow factors [296, 297] (Fig. 3). In addition, certain metabolites of catechin, quercetin 


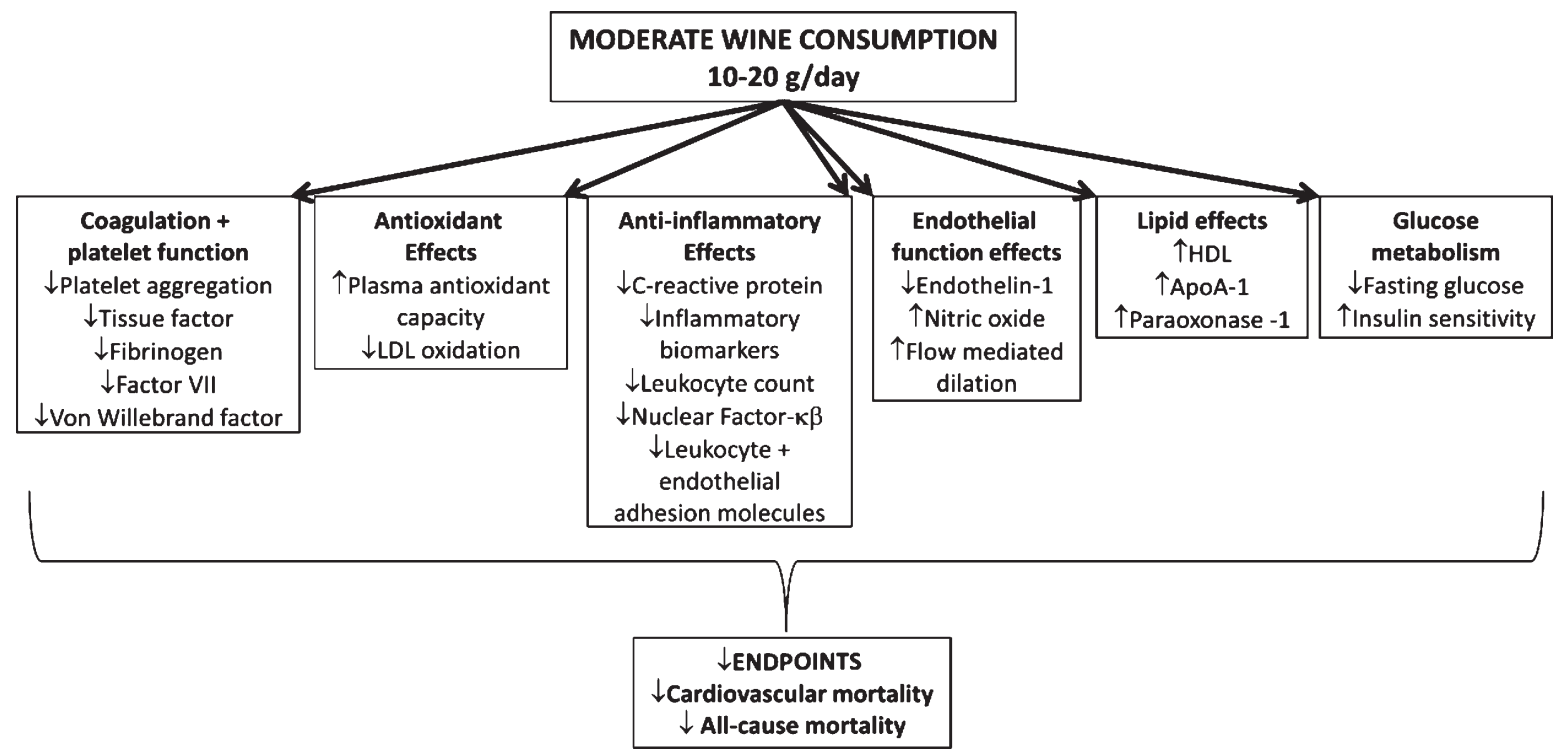

Fig. 2. Cardiovascular effects of moderate red wine consumption. Apo A-1: Apolipoprotein-1; CRP: C-reactive protein; FMD: flow-mediated dilation; HDL: high-density lipoprotein; LDL: low-density lipoprotein; MDA: malon-dialdehyde; NF- $\kappa$ B: nuclear factor- $\kappa$ B; NO: nitric oxide; SOD: superoxide dismutase (adapted from Chiva-Blanch et al. 2013) [174].

and resveratrol, have been shown to exert similar anti-oxidant, endothelial, anti-inflammatory and haemostatic effects in vitro to the parent phenolic compound [19, 299-301].

\subsection{Does pattern of consumption matter?}

Although the J-shaped relationship between alcohol consumption and CVD has been acknowledged in the World Health Organization's Global status report on alcohol (2011), the report also recognises that as well as the amount consumed, the pattern of alcohol consumption also influences the potential health benefits of alcohol consumption [301]. The report includes the following statement: "The relationship between alcohol consumption and cardiovascular diseases is complex. Light to moderate drinking can have a beneficial impact on morbidity and mortality for ischaemic heart disease and ischaemic stroke. However, the beneficial cardioprotective effect of drinking disappears with heavy drinking occasions."

Another relationship that is currently being considered by the WHO is that between different patterns of alcohol consumption and health consequences [302, 303]. Compared to studies examining amount of an alcoholic beverage and CVD risk, there have been relatively few prospective studies examining associations between CVD risk and frequency [175, 304-306].
Consequences such as CVD and specifically CHD, appear to be different depending on whether the same amount of alcohol is consumed in moderation and regularly over a week or on occasions of binge drinking, that is, on irregular heavy drinking occasions. A widely-accepted definition for binge drinking is five or more alcoholic drinks on one occasion, although studies differ in definition [307]. A meta-analysis of six observational studies compared the different drinking patterns. It demonstrated that the dose-response relationship between the amount of alcohol consumed and risk of CHD, for example, was significantly different between regular and irregular consumption [308]. The risk of CHD was increased with irregular consumption compared to abstinence. The irregular pattern appears to modify or negate the cardioprotective effects of alcohol consumption, and is also associated with biological mechanisms that increase the risk of sudden death and stroke [309, 310]. Conversely, regular consumption of any amount appeared cardioprotective. Wine consumption is least associated with irregular heavy patterns and most associated with regular moderate patterns $[311,312]$.

In the US Health Professionals Follow-up Study, among 38,077 men aged 40 to 75 years, consumption of an alcoholic beverage at least three to four days per week was inversely associated with the risk of MI. Consumption with meals did not substantially alter this association. Interestingly, men who increased 


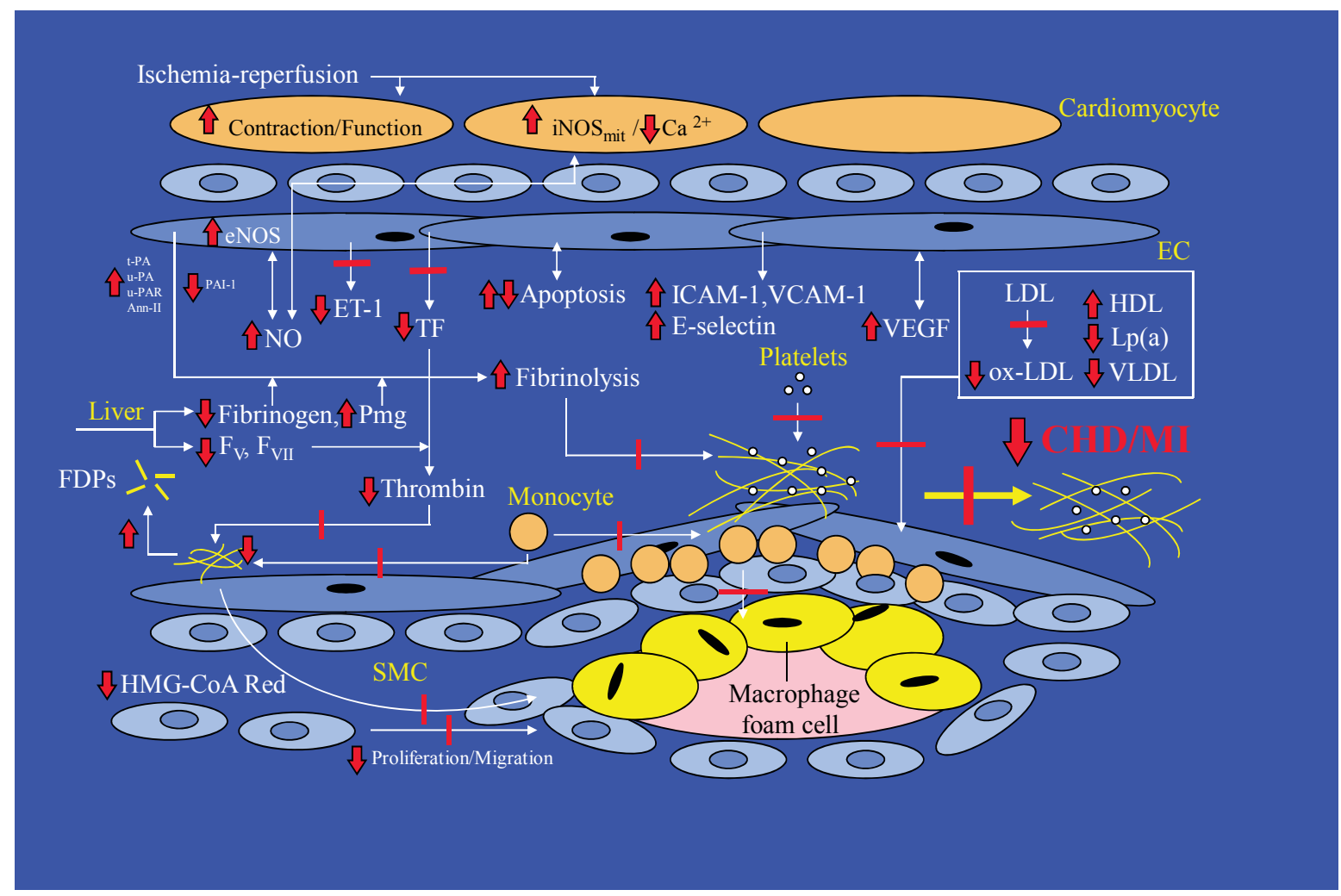

Fig. 3. Proposed cardioprotective mechanisms of the alcohol and the phenolic compound components of wine following regular moderate consumption. Reproduced with permission from Dr F.M. Booyse, Division of Cardiovascular Disease, University of Alabama at Birmingham, Alabama, USA.

their consumption by a moderate amount during the 10 year follow-up had a decreased risk of myocardial infarction [176]. This observation is important given that past consumption habits appear strongly associated with CVD risk and current consumption is most strongly associated with lower risks of CVD and all-cause mortality compared with lifetime abstainers [313]. Similarly, in the UK Whitehall II Cohort Study of 10,308 men aged 35 to 55 years followed for 11 years, the optimal frequency of drinking to reduce the risk of CHD was observed to be between once or twice a week and daily, after adjustment for average volume consumed per week [305]. In a smaller Danish study of 25,052 men and 28,448 woman aged 50 to 65 years followed for approximately six years, the lowest risk of CHD in both men and women was observed with daily consumption of an alcoholic beverage compared with less than once per week [312]. All these findings are supported by a US prospective study of 20,765 current consumers followed for 14 years where the risk of CVD with approximate daily drinking was reduced by $81 \%(1-37 \%)$ [314] compared to the lowest frequency of 36 days/year.

\section{Conclusions and extension of the CVD J-shaped relationship to all-cause mortality}

In 2004/2005, CVD was the most costly disease and represented $11 \%$ of the total health expenditure in Australia. Of CVD expenditure, $40 \%$ was spent on coronary heart disease and stroke, where the majority of expenditure was for hospitalisations (more than $70 \%$ of their respective expenditure) followed by prescription pharmaceuticals (16\% and $11 \%$, respectively) and out-of-hospital services (10\% and 8\%, respectively). Deaths from CVD per se and particularly CHD and stroke increase with age [315]. As a proportion of the population, Australia's population aged 65 years and over is projected to increase from $14 \%$ to between $18.3 \%$ and $19.4 \%$ in 2031 . This increase will have significant implications for Australia in many spheres, including health [316].

The relationship between the consumption of alcoholic beverages and disease morbidity and mortality has been studied for at least five decades. It has been studied at the individual level and at the aggregate 
level, in case-control and in cohort prospective studies, in many countries, looking at both genders and across racial and other population groups.

From these studies, it can be concluded that the risk of CVD overall in the general population can be decreased by at least $25 \%$ with moderate consumption of alcoholic beverages and, in particular, moderate wine consumption. The reduction in CHD risk is major contributor to the overall CVD risk reduction, as it is the most common cardiovascular event.

From the small number of comparative studies, the reduction in risk may be greater for wine than for beer and spirits. The optimal pattern of moderate wine consumption to reduce risk is approximately daily, and the optimal amount is approximately 10 to $20 \mathrm{~g}$ alcohol/day. The meta-analysis by Klatsky and Udaltsova [42] suggests that the cardiprotection extends to approximately $40 \mathrm{~g}$ alcohol/day, as did studies by Doll et al. [317] and Mukamal [23, 50]. The cardioprotection afforded by alcoholic beverages decreases and the risk of any adverse effects increases, however, when consumption increases from light-to-moderate to heavy $[40,104,114,145$, 318].

Extensive biochemical, pharmacological and physiological evidence supports the existence of a causal relationship between regular moderate wine consumption and cardioprotection. Cardioprotection by both the alcohol and phenolic compounds of wine, acting independently and synergistically, is potentially mediated by the following effects: lipid effects predominantly on HDL; haemostatic effects predominantly on plasma fibrinogen concentrations and platelet activation and adhesion; anti-inflammatory effects; effects on endothelial function; and other hormonal effects.

An aim of studies of the consumption of alcoholic beverages and mortality is to establish the net effects of alcohol at the population level and to derive conclusions at the aggregate level. The balance between net health benefits and risks from alcohol consumption is directly related to the distribution of causes of death in a population and to sub groups within a population. These subgroups include young adults, middle aged adults and the elderly. It has been observed for over two decades that the light to moderate consumption of alcoholic beverages such as wine also reduces the risk of death from all-causes within a population [37, 42, 49, 84, 89, 305, 319-321]. This J-shaped relationship between wine and all cause mortality results from the net sum of reduced risks of death from CVD, diabetes, cognitive function disorders such as demen- tia, as well as from certain cancers, and increased risks of death from short-term harms and long-term harms. Short-term harms include accidents such as drowning and suicides, and are generally associated with binge drinking patterns. Long-term harms include certain cancers, liver cirrhosis, pancreatitis and alcohol-related CVD, and are associated with continuous heavier consumption over many years, where risk increases linearly with consumption above moderation.

\section{References}

[1] Laslett LJ, Alagona P Jr, Clark BA 3rd, Drozda JP Jr, Saldivar F, Wilson SR, Poe C, Hart M. The worldwide environment of cardiovascular disease: Prevalence, diagnosis, therapy, and policy issues: A report from the American College of Cardiology. J Am Coll Cardiol. 2012;60(25 Suppl):S1-49.

[2] Booyse FM, Pan W, Grenett HE, Parks DA, Darley-Usmar VM, Bradley KM, Tabengwa EM. Mechanism by which alcohol and wine polyphenols affect coronary heart disease risk. Ann Epidemiol. 2007;17(5 Suppl):S24-31.

[3] Ross R Atherosclerosis is an inflammatory disease. Am Heart J. 1999;138(5 Pt 2):S419-20.

[4] Esposito K, Marfella R, Ciotola M, Di Palo C, Giuglian, F, Giugliano G, D'Armiento M, D'Andrea F, Giugliano, D. Effect of a Mediterranean-style diet on endothelial dysfunction and markers of vascular inflammation in the metabolic syndrome: A randomized trial. JAMA. 2004;292:1440-46.

[5] Lopez-Garcia E, Schulze MB, Fung TT, Meigs JB, Rifai N, Manson JE, Hu FB. Major dietary patterns are related to plasma concentrations of markers of inflammation and endothelial dysfunction Am J Clin Nutr. 2004;80:1029-35.

[6] Collins MA, Neafsey, EJ, Mukamal, KJ, Gray, MO, Parks, DA, Das, DK, Korthuis, RJ. Alcohol in moderation, cardioprotection, and neuroprotection: Epidemiological considerations and mechanistic studies. Alcohol Clin Exp Res. 2009;33:206-19.

[7] Ignarro LJ. Wei Lun Visiting Professorial Lecture: Nitric oxide in the regulation of vascular function: An historical overview. J Card Surg. 2002;17:301-6.

[8] Lerman A, Zeiher AM. Endothelial function: Cardiac event.s Circulation. 2005;111(3):363-8.

[9] Tunstall-Pedoe H, Kuulasmaa K, Mähönen M, Tolonen H, Ruokokoski E, Amouyel P. Contribution of trends in survival and coronary-event rates to changes in coronary heart disease mortality: 10-year results from 37 WHO MONICA project populations. Monitoring trends and determinants in cardiovascular disease. Lancet. 1999;353(9164):1547-57.

[10] Tunstall-Pedoe H, Kuulasmaa K, Amouyel P, Arvellier D, Rajakangas AM, Pajal A. Myocardial infarction and coronary deaths in the World Health Organisation MONICA project: Registration procedures, event rates and case fatality rates in 38 populations from 21 countries in four continents Circulation. 1994;90:583-12.

[11] Evans A, Tolonen H, Hense HW, Ferrario M, Sans S, Kuulasmaa K. WHO MONICA Project. Trends in coronary risk 
factors in the WHO MONICA project. Int J Epidemiol. 2001;30 Suppl 1:S35-40.

[12] Tolonen H, Mähönen M, Asplund K, Rastenyte D, Kuulasmaa K, Vanuzzo D, Tuomilehto J. Do trends in population levels of blood pressure and other cardiovascular risk factors explain trends in stroke event rates? Comparisons of 15 populations in 9 countries within the WHO MONICA Stroke Project World Health Organization. Monitoring of Trends and Determinants in Cardiovascular Disease. Stroke. 2002;33(10):2367-75.

[13] Begg S, Vos T, Barker B, Stevenson C, Stanley L, Lopez AD. The burden of disease and injury in Australia 2003. PHE 82 Canberra: AIHW; 2007.

[14] AIHW (2013) Trends in cardiovascular disease Australian Institute of Health and Welfare, Canberra http:// wwwaihwgovau/cardiovascular-health/trends/

[15] World Health Organization. Global status report on alcohol and health. Geneva, Switzerland: World Health Organisation; 2014.

[16] Kawashima S, Yamashita T, Ozaki M, Ohashi Y, Azumi $\mathrm{H}$, Inoue N, Hirata K, Hayashi Y, Itoh H, Yokoyama M. Endothelial NO synthase overexpression inhibits lesion formation in mouse model of vascular remodelling. Arterioscler Thromb Vasc Biol. 2001;21(2):201-7.

[17] Shield KD, Rylett M, Gmel G, Gmel G, Kehoe-Chan TA, Rehm J. Global alcohol exposure estimates by country, territory and region for 2005-a contribution to the Comparative Risk Assessment for the 2010 Global Burden of Disease Study. Addiction. 2013;108(5):912-22.

[18] Rapp A, Mandery H. Wine aroma. Experientia. 1986;42: 873-84.

[19] Day RE, Gishen M, Godden PW, Hughes JB. Producing unique wine styles for overseas markets In: Blair RJ, Williams P, Høj PB, editors. Proceedings of the eleventh Australian wine industry technical conference; 7-11 October 2001; Adelaide, SA; 2002: pp. 27-30.

[20] Lian C. L'alcoolisme, cause d'hypertension arterielle. Bull Acad Med. 1915;74:525-8.

[21] Klatsky AL, Friedman GD, Siegelaub AB. Alcohol consumption before myocardial infarction Results from the Kaiser-Permanente epidemiologic study of myocardial infarction. Ann Intern Med. 1974;81(3):294-301.

[22] St Leger AS, Cochrane AL, Moore F. Factors associated with cardiac mortality in developed countries with particular reference to the consumption of wine Lancet. 1979;1(8124):1017-20.

[23] Mukamal KJ, Chen CM, Rao SR, Breslow RA. Alcohol consumption and cardiovascular mortality among US adults, 1987 to 2002. J Am Coll Cardiol. 2010;55(13):132835.

[24] World Health Organization. Global strategy to reduce harmful use of alcohol. Geneva, Switzerland: World Health Organisation; 2010.

[25] World Health Organization. Global status report on alcohol and health. Geneva, Switzerland: World Health Organisation; 2014.

[26] Gordon T, Kannel WB. Drinking habits and cardiovascular disease: The Framingham study. Am Heart J. 1985;110: 331-34.

[27] Boffetta P, Garfinkel L. Alcohol drinking and mortality among men enrolled in an American Cancer Society prospective study. Epidemiol. 1990;1:342-48.
[28] Rimm EB, Giovannucci EL, Willett WC, Colditz GA, Ascherio A, Rosner B, Stampfer MJ. Prospective study of alcohol consumption and risk of coronary disease in men. Lancet. 1991;338(8765):464-8.

[29] Farchi G, Fidanza F, Mariotti S, Menotti A. Alcohol and mortality in the Italian rural cohorts of the Seven Countries Study. International Journal of Epidemiology. 1992;21: 74-81.

[30] Renuad S, de Lorgeril M. The French Paradox: Dietary factors for coronary heart disease. Lancet. 1992;339: 1523-6.

[31] Doll R, Peto R, Hall E, Wheatley K, Gray R. Mortality in relation to consumption of alcohol: 13 years' observations on male British doctors. BMJ. 1994;309(6959):911-8

[32] Goldberg RJ, Burchfiel CM, Reed DM, Wergowske G, Chiu D. A prospective study of the health effects of alcohol consumption in middle-aged and elderly men. The honolulu heart program. Circulation. 1994;89(2):651-9.

[33] Shaper AG, Wannamethee G, Walker M.Alcohol and coronary heart disease: A perspective from the British Regional Heart Study. Int J Epidemiol. 1994;23(3):482-94.

[34] Fuchs CS, Stampfer MJ, Colditz GA, Giovannucci EL, Manson JE, Kawachi I, Hunter DJ, Hankinso, SE, Hennekens CH, Rosner B, Speizer FE, Willett WC. Alcohol consumption and mortality among women. N Engl J Med. 1995;332:1245-50.

[35] Camargo Jr, CA, Hennekens CH, Gaziano JM, Glynn RJ, Manson JE, Stampfer MJ. Prospective Study of Moderate Alcohol Consumption and Mortality in US Male Physicians. Arch Intern Med. 1997;157(1):79-85.

[36] Thun MJ, Peto R, Lopez A, Monaco JH, Henley SJ, Heath CW, Doll. R. Alcohol consumption and mortality among middle-aged and elderly US adults. N Engl J Med. 1997;337:1705-14.

[37] Gaziano JM, Gaziano TA, Glynn RJ, Sesso HD, Ajani UA, Stampfer MJ, Manson JE, Hennekens CH, Buring JE. Light-to-moderate alcohol consumption and mortality in the Physicians' Health Study enrollment cohort. J Am Coll Cardiol. 2000;35(1):96-105.

[38] Emberson JR, Shaper AG, Wannamethee SG, Morris RW, Whincup PH. Alcohol intake in middle age and risk of cardiovascular disease and mortality: Accounting for intake variation over time. Am J Epidemiol. 2005;161(9):856-63.

[39] Schröder H, Ferrández O, Jimenez Conde J, Sánchez-Font A, Marrugat J. Cardiovascular risk profile and type of alcohol beverage consumption: A population-based study. Ann Nutr Metab. 2005;49(2):100-6.

[40] Costanzo S, Di Castelnuovo A, Donati MB, Iacoviello L, de Gaetano G. (2010) Cardiovascular and overall mortality risk in relation to alcohol consumption in patients with cardiovascular disease. Circulation. 2010;121(17):1951-9.

[41] Corrao G, Bagnardi V, Zambon A, La Vecchia C. A metaanalysis of alcohol consumption and the risk of 15 diseases. Prev Med. 2004;38(5):613-19.

[42] Klatsky AL, Udaltsova N. Alcohol drinking and total mortality risk. Ann Epidemiol. 2007;17(5, Supplement 1):S63-7.

[43] Jackson R, Broad J, Connor S, Wells S. Alcohol and ischaemic heart disease: Probably no free lunch. Lancet. 2005;366(9501):1911-12.

[44] Fillmore KM, Kerr WC, Stockwell T, Chikritzhs T, Bostrom A. Moderate alcohol use and reduced mortality risk: 
Systematic error in prospective studies. Addict Res Theory. 2006;14(2):101-12.

[45] Fillmore KM, Stockwell T, Chikritzhs T, Bostrom A, Kerr W. Moderate alcohol use and reduced mortality risk: Systematic error in prospective studies and new hypotheses Ann Epidemiol. 2007;17(5, Supplement 1):S16-S23.

[46] Fuller TD. Moderate alcohol consumption and the risk of mortality Demography. 2011;48(3):1105-25.

[47] Klatsky AL, Chartier D, Udaltsova N, Gronningen S, Brar S, Friedman GD, Lundstrom RJ. Alcohol drinking and risk of hospitalization for heart failure with and without associated coronary artery disease. Am J Cardiol. 2005;96(3):346-51.

[48] Tolvanen E, Seppä K, Lintonen T, Paavilainen P, Jylhä M. Old people, alcohol use and mortality A ten-year prospective study. Aging Clin Exp Res. 2005;17(5):426-33.

[49] Di Castelnuovo A, Costanzo S, Bagnardi V, Donati MB, Iacoviello L, de Gaetano G. Alcohol dosing and total mortality in men and women: An updated meta-analysis of 34 prospective studies. Arch Intern Med. 2006;166: 2437-45.

[50] Mukamal KJ, Chiuve SE, Rimm EB. Alcohol consumption and risk for coronary heart disease in men with healthy lifestyles. Arch Intern Med. 2006;166(19):2145-50.

[51] Harriss LR, English DR, Hopper JL, Powles J, Simpson JA, O'Dea K, Giles GG, Tonkin AM. Alcohol consumption and cardiovascular mortality accounting for possible misclassification of intake: 11-year follow-up of the Melbourne Collaborative Cohort Study. Addiction. 2007;102(10): 1574-85.

[52] Rimm EB, Moats C. Alcohol and coronary heart disease: Drinking patterns and mediators of effect. Annal Epidemiol. 2007;15(7): S3-S7.

[53] Athyros VG, Liberopoulos EN, Mikhailidis DP, Papageorgiou AA, Ganotakis ES, Tziomalos K, Kakafika AI, Karagiannis A, Lambropoulos S, Elisaf M. Association of drinking pattern and alcohol beverage type with the prevalence of metabolic syndrome, diabetes, coronary heart disease, stroke, and peripheral arterial disease in a Mediterranean cohort. Angiology. 2007;58(6):689-97.

[54] Djoussé L, Driver JA, Gaziano JM. Relation between modifiable lifestyle factors and lifetime risk of heart failure. JAMA. 2009;302(4):394-400.

[55] Streppel MT, Ocké MC, Boshuizen HC, Kok FJ, Kromhout D. Long-term wine consumption is related to cardiovascular mortality and life expectancy independently of moderate alcohol intake: The Zutphen Study. J Epidemiol Community Health. 2009;63(7):534-40.

[56] Holahan CJ, Schutte KK, Brennan PL, Holahan CK, Moos BS, Moos RH. Late-life alcohol consumption and 20-year mortality. Alcohol Clin Exp Res. 2010;34(11): 1961-71.

[57] Howie EK, Sui X, Lee DC, Hooker SP, Hébert JR, Blair SN. Alcohol consumption and risk of all-cause and cardiovascular disease mortality in men. J Aging Res. 2011:805062. doi: 104061/2011/805062

[58] Rostron B. Alcohol consumption and mortality risks in the USA Alcohol Alcohol. 2012;47(3):334-9.

[59] Djoussé L, Lee IM, Buring JE, Gaziano JM. Alcohol consumption and risk of cardiovascular disease and death in women: Potential mediating mechanisms. Circulation. 2009;120(3):237-44.
[60] Miller GJ, Beckles GL, Maude GH, Carson DC. Alcohol consumption: Protection against coronary heart disease and risks to health Int J Epidemiol. 1990;19:923-30.

[61] Maskarinec G, Meng L, Kolonel LN. Alcohol intake, body weight, and mortality in a multiethnic prospective cohort. Epidemiology. 1998;9:654-61.

[62] Yusuf S, Hawken S, Ounpuu S, Dans T, Avezum A, Lanas F, McQueen M, Budaj A, Pais P, Varigos J, Lisheng L, INTERHEART Study Investigators. Effect of potentially modifiable risk factors associated with myocardial infarction in 52 countries (the INTERHEART study): Casecontrol study. Lancet. 2004;364(9438): 937-52.

[63] Lin Y, Kikuchi S, Tamakoshi A, Wakai K, Kawamura T, Iso H, Ogimoto I, Yagyu K, Obata Y, Ishibashi T, JACC Study Group. Alcohol consumption and mortality among middleaged and elderly Japanese men and women Ann Epidemiol. 2005;15(8):590-7.

[64] Gyárfás I, Keltai M, Salim Y. [Effect of potentially modifiable risk factors associated with myocardial infarction in 52 countries in a case-control study based on the INTERHEART study]. Orv Hetil. 2006;147(15):675-86.

[65] Carević V, Rumboldt M, Rumboldt Z; Interheart Investigators. [Coronary heart disease risk factors in Croatia and worldwide: Results of the Interheart study] Acta Med Croatica. 2007;61(3): 299-306.

[66] Ikehara S, Iso H, Toyoshima H, Date C, Yamamoto A, Kikuchi S, Kondo T, Watanabe Y, Koizumi A, Wada Y, Inaba Y, Tamakoshi A, Japan Collaborative Cohort Study Group. Alcohol consumption and mortality from stroke and coronary heart disease among Japanese men and women: The Japan collaborative cohort study. Stroke. 2008;39(11): 2936-42.

[67] Wen W, Xiang YB, Zheng W, Xu WH, Yang G, Li H, Shu $\mathrm{XO}$. The association of alcohol, tea, and other modifiable lifestyle factors with myocardial infarction and stroke in Chinese men. CVD Prev Control. 2008;3(3):133-40.

[68] Waśkiewicz A, Sygnowska E, Drygas W. Relationship between alcohol consumption and cardiovascular mortality-the Warsaw Pol-MONICA Project. Kardiol Pol. 2004;60(6):552-62; discussion 563.

[69] Bryson CL, Mukamal KJ, Mittleman MA, Fried LP, Hirsch $\mathrm{CH}$, Kitzman DW, Siscovick DS. The association of alcohol consumption and incident heart failure: The Cardiovascular Health Study. J Am Coll Cardiol. 2006;48(2):305-11.

[70] Mukamal KJ, Ding EL, Djoussé L. Alcohol consumption, physical activity, and chronic disease risk factors: A population-based cross-sectional survey. BMC Public Health. 2006;6:118.

[71] Ford ES, Zhao G, Tsai K, Li C. Low-risk lifestyle behaviors and all-cause mortality: Findings from the National Health and Nutrition Examination Survey III Mortality Study. Am J Pub Health. 2011;101:1922-29.

[72] Shuval K, Barlow CE, Chartier KG, Gabriel KP. Cardiorespiratory fitness, alcohol, and mortality in men: The Cooper Center longitudinal study. Am J Prev Med. 2012;42(5): 460-7.

[73] Soedamah-Muthu SS, De Neve M, Shelton NJ, Tielemans SM, Stamatakis E. Joint associations of alcohol consumption and physical activity with all-cause and cardiovascular mortality. Am J Cardiol. 2013;112(3):380-6.

[74] Marmot MG. Alcohol and coronary heart disease. Int $\mathbf{J}$ Epidemiol. 2001;30(4):724-9. 
[75] Costanzo S, Di Castelnuovo A, Donati MB, Iacoviello L, de Gaetano G. Wine, beer or spirit drinking in relation to fatal and non-fatal cardiovascular events : A meta-analysis Eur J Epidemiol. 2011;26(11):833-50.

[76] Inoue M, Nagata C, Tsuji I, Sugawara Y, Wakai K, Tamakoshi A, Matsuo K, Mizoue T, Tanaka K, Sasazuki S, Tsugane S, Research Group for the Development and Evaluation of Cancer Prevention Strategies in Japan. Impact of alcohol intake on total mortality and mortality from major causes in Japan: A pooled analysis of six large-scale cohort studies. J Epidemiol Community Health. 2012;66(5): 448-56.

[77] Maclure M. Demonstration of Deductive Meta-Analysis: Ethanol Intake and Risk of Myocardial Infarction Epidemiol Rev. 1993;15(2):328-51.

[78] Corrao G, Rubbiati L, Bagnardi V, Zambon A, Poikolainen, K. Alcohol and coronary heart disease: A meta-analysis Addiction. 2000;95:1505-23.

[79] Liu PM, Dosieah S, Zheng HS, Huang ZB, Lin YQ, Wang JF. [Alcohol consumption and coronary heart disease in Eastern Asian men: A meta-analysis of prospective cohort studies] Zhonghua Xin Xue Guan Bing Za Zhi. 2010;38(11):1038-44.

[80] Roerecke M, Rehm J. The cardioprotective association of average alcohol consumption and ischaemic heart disease: A systematic review and meta-analysis Addiction. 2012;107(7):1246-60.

[81] Padilla H, Michael Gaziano J, Djoussé L. Alcohol consumption and risk of heart failure: A meta-analysis. Phys Sportsmed. 2010;38(3):84-9.

[82] Wilsnack SC, Wilsnack RW, Kantor LW. Focus on: Women and the costs of alcohol use. Alcohol Res. 2013;35(2):21928.

[83] Ronksley PE, Brien SE, Turner BJ, Mukamal KJ, Ghali WA. Association of alcohol consumption with selected cardiovascular disease outcomes: A systematic review and meta-analysis Br Med J. 2011;34(3):363-70.

[84] Holman CDJ, English DR, Milne E, Winter MG. Metaanalysis of alcohol and all-cause mortality: A validation of NHMRC recommendations. Med J Aust. 1996;164: 141-5.

[85] Rehm J, Sempos CT. Alcohol consumption and all-cause mortality. Addiction. 1995;90(4):471-80.

[86] Tolstrup J, Grönbeck M. Alcohol and atherosclerosis: Recent insights. Curr Atheroscler Rep. 2007;9:116-24.

[87] Hvidtfeldt UA, Tolstrup JS, Jakobsen MU, Heitmann BL, Grønbaek M, O'Reilly E, Bälter K, Goldbourt U, Hallmans G, Knekt P, Liu S, Pereira M, Pietinen P, Spiegelman D, Stevens J, Virtamo J, Willett WC, Rimm EB, Ascherio A. Alcohol and intake and risk of coronary heart disease in younger, middle-aged and older adults. Circulation. 2010;121:1589-97.

[88] Stampfer, MJ, Colditz, GA, Willett, WC, Speizer, FE and Hennekens, $\mathrm{CH}$. A prospective study of moderate alcohol consumption and the risk of coronary disease and stroke in women. N Engl J Med. 1988;319:267-73.

[89] Klatsky AL, Armstrong MA, Friedman GD. Alcohol and mortality Ann Intern Med. 1992;117(8):646-54.

[90] Snow WM, Murray R, Ekuma O, Tyas SL, Barnes GE. Alcohol use and cardiovascular health outcomes: A comparison across age and gender in the Winnipeg Health and Drinking Survey Cohort. Age Ageing. 2009;38(2):206-12.
[91] Sesso HD, Stampfer MJ, Rosner B, Hennekens CH, Manson JE, Gaziano JM. Seven-year changes in alcohol consumption and subsequent risk of cardiovascular disease in men. Arch Intern Med. 2000;160(17): 2605-12.

[92] Friesema IH, Zwietering PJ, Veenstra MY, Knottnerus JA, Garretsen HF, Lemmens PH. Alcohol intake and cardiovascular disease and mortality: The role of pre-existing disease. J Epidemiol Community Health. 2007;61(5):441-6.

[93] King DE, Mainous AG 3rd, Geesey ME. Adopting moderate alcohol consumption in middle age: Subsequent cardiovascular events. Am J Med. 2008;121(3):201-6.

[94] Simons L, McCallum AJ, Friedlander Y, Ortiz M, Simons J. Moderate alcohol intake is associated with survival in the elderly: The Dubbo Study. Med J Aust. 2000;173(3): 1211-24.

[95] Perissinotto E, Buja A, Maggi S, Enzi G, Manzato E, Scafato E, Mastrangelo G, Frigo AC, Coin A, Crepaldi G, Sergi G, ILSA Working Group. Alcohol consumption and cardiovascular risk factors in older lifelong wine drinkers: The Italian Longitudinal Study on Aging. Nutr Metab Cardiovasc Dis. 2010;20(9):647-55.

[96] McCaul KA, Almeida OP, Hankey GJ, Jamrozik K, Byles JE, Flicker L. Alcohol use and mortality in older men and women. Addiction. 2010;105(8):1391-400.

[97] Simons L. Alcohol intake and survival in Australian seniors: The Dubbo Study. Nutr Aging. 2014;2(2-3):85-90.

[98] Power C, Rodgers B, Hope S. U-shaped relation for alcohol consumption and health in early adulthood and implications for mortality Lancet. 1998;352:877.

[99] Green D, Foiles N, Chan C, Schreiner PJ, Liu K. Elevated fibrinogen levels and subsequent subclinical atherosclerosis: The CARDIA Study. Atherosclerosis. 2009;202(2): 623-31.

[100] Wakabayashi I, Araki Y. Influences of gender and age on relationships between alcohol drinking and atherosclerotic risk factors Alcohol Clin Exp Res. 2010;34(Suppl 1): S54-60.

[101] Okwuosa TM, Klein O, Chan C, Schreiner P, Liu K, Green D. Long-term change in alcohol-consumption status and variations in fibrinogen levels: The coronary artery risk development in young adults (CARDIA) study. BMJ. 2013;3(7). pii: e002944. doi: 10.1136/bmjopen2013-002944

[102] Kiyohara Y, Kato I, Iwamoto H, Nakayama K, Fujishima M. The impact of alcohol and hypertension on stroke incidence in a general Japanese population The Hisayama Study. Stroke. 1995;26(3):368-72.

[103] Palmer AJ, Fletcher AE, Bulpitt CJ, Beevers DG, Coles EC, Ledingham JG, et al. Alcohol intake and cardiovascular mortality in hypertensive patients: Report from the Department of Health Hypertension Care Computing Project. J Hypertens. 1995;13:957-64.

[104] Malinski MK, Sesso HD, Lopez-Jimenez F, Buring JE, Gaziano JM. Alcohol consumption and cardiovascular disease mortality in hypertensive men. Arch Intern Med. 2004; 164:623-28.

[105] Reims HM, Kjeldsen SE, Brady WE, Dahlof B, Devereux $\mathrm{RB}$, Julius $\mathrm{S}$, et al. Alcohol consumption and cardiovascular risk in hypertensives with left ventricular hypertrophy: The LIFE study. J Hum Hypertens. 2004;18:381-89.

[106] Renaud SC, Gueguen R, Conard P, Lanzmann-Petithory D, Orgogozo JM, Henry O. Moderate wine drinkers have lower 
hypertension-related mortality: A prospective cohort study in French men. Am J Clin Nutr. 2004;80:621-5.

[107] Beulens JW, Rimm EB, Ascherio A, Spiegelman D, Hendriks HF, Mukamal KJ. Alcohol consumption and risk for coronary heart disease among men with hypertension. Ann Intern Med. 2007;146(1):10-19.

[108] Djoussé L, Gaziano JM. Alcohol consumption and heart failure in hypertensive US male physicians. Am J Cardiol. 2008;102(5):593-7.

[109] Bos S, Grobbee DE, Boer JM, Verschuren WM, Beulens JW. Alcohol consumption and risk of cardiovascular disease among hypertensive women. Eur J Cardiovasc Prev Rehabil. 2010;17(1):119-26.

[110] Britton KA, Gaziano JM, Sesso HD, Djoussé L. Relation of alcohol consumption and coronary heart disease in hypertensive male physicians (from the Physicians' Health Study). Am J Cardiol. 2009;104(7):932-5.

[111] Brügger-Andersen T, Pönitz V, Snapinn S, Dickstein K, OPTIMAAL study group. Moderate alcohol consumption is associated with reduced long-term cardiovascular risk in patients following a complicated acute myocardial infarction. Int J Cardiol. 2009;133(2):229-32.

[112] Gisbertz SS, Derksen WJ, de Kleijn DP, Vink A, Bots ML, de Vries JP, Moll FL, Pasterkamp G. The effect of alcohol on atherosclerotic plaque composition and cardiovascular events in patients with arterial occlusive disease. J Vasc Surg. 2011;54(1):123-31.

[113] Pai JK, Mukamal KJ, Rimm EB. Long-term alcohol consumption in relation to all-cause and cardiovascular mortality among survivors of myocardial infarction: The Health Professionals Follow-up Study. Eur Heart J. 2012;33(13):1598-605.

[114] Jackson VA, Sesso HD, Buring JE, Gaziano JM. Alcohol consumption and mortality in men with preexisting cerebrovascular disease. Arch Intern Med. 2003;163(10): 1189-93.

[115] Abramson JL, Williams SA, Krumholz HM, Vaccarino V. Moderate alcohol consumption and risk of heart failure among older persons. JAMA. 2001;285:1971-7.

[116] Gillman MW, Cook NR, Evans DA, Rosner B, Hennekens $\mathrm{CH}$. Relationship of alcohol intake with blood pressure in young adults. Hypertension. 1995;25(5):1106-10.

[117] Thadhani R, Camargo CA Jr, Stampfer MJ, Curhan GC, Willett WC, Rimm EB. Prospective study of moderate alcohol consumption and risk of hypertension in young women Arch Intern Med. 2002;162(5): 569-74.

[118] Walsh CR, Larson MG, Evans JC et al. Alcohol consumption and risk for congestive heart failure in the Framingham Heart study. Ann Intern Med. 2002;136:181-91.

[119] Djoussé L, Levy D, Benjamin EJ, Blease SJ, Russ A, Larson MG, Massaro JM, D’Agostino RB, Wolf PA, Ellison RC. Long-term alcohol consumption and the risk of atrial fibrillation in the Framingham Study Am J Cardiol. 2004;93(6):710-3.

[120] Elkind MS, Sciacca R, Boden-Albala B, Rundek T, Paik MC, Sacco RL. Moderate alcohol consumption reduces risk of ischemic stroke: The Northern Manhattan Study. Stroke. 2006;37(1):13-9.

[121] Samokhvalov AV, Irving HM, Rehm J. Alcohol consumption as a risk factor for atrial fibrillation: A systematic review and meta-analysis. Eur J Cardiovasc Prev Rehabil. 2010;17(6):706-12.
[122] Kodama S, Saito K, Tanaka S, Horikawa C, Saito A, Heianza Y, Anasako Y, Nishigaki Y, Yachi Y, Iida KT, Ohashi Y, Yamada N, Sone H. Alcohol consumption and risk of atrial fibrillation: A meta-analysis J Am Coll Cardiol. 2011;57(4):427-36.

[123] Lloyd-Jones DM. The risk of congestive heart failure: Sobering lessons from the Framingham Heart Study. Curr Cardiol Rep. 2001; 3(3):184-90.

[124] Wilhelmsen L, Rosengren A, Eriksson H, Lappas G. Heart failure in the general population of men-morbidity, risk factors and prognosis. J Intern Med. 2001;249(3):253-61.

[125] Habuchi Y, Furukawa T, Tanaka H, Lu LL, Morikawa J, Yoshimura M. Ethanol inhibition of $\mathrm{Ca} 2+$ and $\mathrm{Na}+$ currents in the guinea-pig heart. Eur J Pharmacol. 1995;292(2): 143-9.

[126] Steinbigler P, Haberl R, König B, Steinbeck G. P-wave signal averaging identifies patients prone to alcoholinduced paroxysmal atrial fibrillation. Am J Cardiol. 2003;91(4):491-4.

[127] Marcus GM, Smith LM, Whiteman D, Tseng ZH, Badhwar N, Lee BK, Lee RJ, Scheinman MM, Olgin JE. Alcohol intake is significantly associated with atrial flutter in patients under 60 years of age and a shorter right atrial effective refractory period. Pacing Clin Electrophysiol. 2008;31(3):266-72.

[128] Nanchahal K, Ashton WD, Wood DA. Alcohol consumption, metabolic cardiovascular risk factors and hypertension in women. Int J Epidemiol. 2000;29(1):57-64.

[129] Xin X, He J, Frontini MG, Ogden LG, Motsamai OI, Whelton PK. Effects of alcohol reduction on blood pressure: A meta-analysis of randomized controlled trials Hypertension. 2001;38(5):1112-7.

[130] Sesso HD, Cook NR, Buring JE, Manson JE, Gaziano JM. Alcohol consumption and the risk of hypertension in women and men Hypertension. 2008;51(4): 1080-7.

[131] Taylor B, Irving HM, Baliunas D, Roerecke M, Patra J, Mohapatra S, Rehm J. Alcohol and hypertension: Gender differences in dose-response relationships determined through systematic review and meta-analysis. Addiction. 2009;104(12):1981-90.

[132] Briasoulis A, Agarwal V, Messerli FH. Alcohol consumption and the risk of hypertension in men and women: A systematic review and meta-analysis. J Clin Hypertens (Greenwich). 2012;14(11):792-8.

[133] Manolio TA, Kronmal RA, Burke GL, O'Leary DH, Price TR. Short-term predictors of incident stroke in older adults. The Cardiovascular Health Study Stroke. 1996;27(9):147986.

[134] Klatsky AL, Armstrong MA, Friedman GD, Sidney S. Alcohol drinking and risk of hospitalization for ischemic stroke. Am J Cardiol. 2001;88(6):703-6.

[135] Reynolds K, Lewis B, Nolen JD, Kinney GL, Sathya B, He J. Alcohol consumption and risk of stroke: A meta-analysis. JAMA. 2003;289(5):579-88.

[136] Mukamal KJ, Chung H, Jenny NS, Kuller LH, Longstreth WT Jr, Mittleman MA, Burke GL, Cushman M, Beauchamp NJ Jr, Siscovick DS. Alcohol use and risk of ischemic stroke among older adults: The cardiovascular health study. Stroke. 2005;36(9):1830-4.

[137] Mukamal KJ, Ascherio A, Mittleman MA, Conigrave KM, Camargo CA Jr, Kawachi I, Stampfer MJ, Willett WC, 
Rimm EB. Alcohol and risk for ischemic stroke in men: The role of drinking patterns and usual beverage. Ann Intern Med. 2005;142(1):11-9.

[138] Ruidavets J-B, Ducimetièere, P, Evans A, Montaye M, Haas B, Bingham A, Yarnell J, Amouye, P, Arveiler, D, Kee F, Bongard V, Ferrières J. Patterns of alcohol consumption and ischaemic heart disease in culturally divergent countries: The Prospective Epidemiological Study of Myocardial Infarction (PRIME). Br Med J. 2010;341:c6077. doi:101136/bmjc6077

[139] Klatsky AL, Armstrong MA, Friedman GD, Sidney S. Alcohol drinking and risk of hemorrhagic stroke. Neuroepidemiology. 2002;21(3):115-22.

[140] Ariesen MJ, Claus SP, Rinkel GJ, Algra A. Risk factors for intracerebral hemorrhage in the general population: A systematic review. Stroke. 2003;34(8):2060-5.

[141] Feigin VL, Rinkel GJ, Lawes CM, Algra A, Bennett DA, van Gijn J, Anderson CS. Risk factors for subarachnoid hemorrhage: An updated systematic review of epidemiological studies. Stroke. 2005;36(12):2773-80.

[142] Patra J, Taylor B, Irving H, Roerecke M, Baliunas D, Mohapatra S, Rehm J. Alcohol consumption and the risk of morbidity and mortality for different stroke types-a systematic review and meta-analysis. BMC Public Health. 2010;10:258.

[143] Iso H, Baba S, Mannami T, Sasaki S, Okada K, Konishi M, Tsugane S, JPHC Study Group. Alcohol consumption and risk of stroke among middle-aged men: The JPHC Study Cohort I. Stroke. 2004;35(5):1124-9.

[144] Renaud S, de lorgeril M. Wine, alcohol, platelets, and the French paradox for coronary heart disease. Lancet. 1992:339(8808):1523-6.

[145] Rimm, EB, Williams, P, Fosher, K, Criqui, M, Stampfer, MJ. Moderate alcohol intake and lower risk of coronary heart disease: Meta-analysis of effects on lipids and haemostatic factors. Br Med J. 1999:319(7224):1523-8.

[146] Hines LM, Rimm EB. Moderate alcohol consumption and coronary heart disease: A review. Postgrad Med J. 2001;77(914):747-52.

[147] Brien SE, Ronksley PE, Turner BJ, Mukamal KJ, Ghali WA. Effect of alcohol consumption on biological markers associated with risk of coronary heart disease: Systematic review and meta-analysis of interventional studies. Br Med J. 2011;342:d636; doi:101136/bmjd636

[148] Rimm EB, Klatsky A, Grobbee D, Stampfer MJ. Review of moderate alcohol consumption and risk of coronary heart disease: Is the effect due to beer, wine or spirits? Br Med J. 1996;312:731-6.

[149] Djoussé L, Himali JJ, Beiser A, Kelly-Hayes M, Wolf PA. Apolipoprotein e, alcohol consumption, and risk of ischemic stroke: The framingham heart study revisited. J Stroke Cerebrovasc Dis. 2009;18(5):384-8.

[150] Chambless LE, Heiss G, Folsom AR, Rosamond W, Szklo M, Sharrett AR, Clegg LX. Association of coronary heart disease incidence with carotid arterial wall thickness and major risk factors: The Atherosclerosis Risk in Communities (ARIC) Study, 1987-1993 Am J Epidemiol. 1997;146(6):483-94.

[151] Durrington PN. How HDL protects against atheroma. Lancet. 1993; 342:1315-6.

[152] Klimov AN, Gurevich VS, Nikiforova AA, Shatilina LV, Kuzmi, AA, Plavinsky SL, Teryukova NP. Antioxidative activity of high density lipoproteins in vivo Atherosclerosis. 1993;100(1):13-18.

[153] Mackness MI, Abbott C, Arrol S, Durrington PN. The role of high-density lipoprotein and lipid-soluble antioxidant vitamins in inhibiting low-density lipoprotein oxidation. Biochem J. 1993;294:829-34.

[154] Parker DR, McPhillips JB, Derby CA, Gans KM, Lasater TM, Carleton RA. High-density-lipoprotein cholesterol and types of alcoholic beverages consumed among men and women. Am J Public Health. 1996;86(7):1022-7.

[155] Ruidavets JB, Ducimetière P, Arveiler D, Amouyel P, Bingham A, Wagner A, Cottel D, Perret B, Ferrières J. Types of alcoholic beverages and blood lipids in a French population. J Epidemiol Community Health. 2002;56(1):24-8.

[156] de Jong HJ, de Goede J, Oude Griep LM, Geleijnse JM. Alcohol consumption and blood lipids in elderly coronary patients Metabolism. 2008;57(9):1286-92.

[157] Branchi A, Rovellini A, Tomella C, Sciariada L, Torri A, Molgora M, Sommariva D (1997) Association of alcohol consumption with HDL subpopulations defined by apolipoprotein A-I and apolipoprotein A-II content. Eur J Clin Nutr. 1997;51(6):362-5.

[158] Sierksma A, van der Gaag MS, Kluft C, Hendriks HF. Effect of moderate alcohol consumption on fibrinogen levels in healthy volunteers is discordant with effects on C-reactive protein. Ann NY AcadSci. 2002;936:630-3.

[159] Hendriks HFJ, Veenstra J, Velthuis TE, Wierik EJM, Scaafsma G, Kluft C. Effect of moderate dose of alcohol with evening meal on fibrinolytic factors. Br Med J. 1994;308:1003-6.

[160] Hendriks HF, van der Gaag MS. Alcohol, coagulation and fibrinolysis Novartis Found Symp. 1998;216:111-20; discussion 120-4.

[161] Lacoste L, Hung J, Lam JY. Acute and delayed antithrombotic effects of alcohol in humans. Am J Cardiol. 2001;87(1):82-5.

[162] Fan J, Watanabe T. Inflammatory reactions in the pathogenesis of atherosclerosis. J Atheroscler Thromb. 2003;10(2):63-71.

[163] Mangge H, Hubmann H, Pilz S, Schauenstein K, Renner W, März W. Beyond cholesterol-inflammatory cytokines, the key mediators in atherosclerosis Clin Chem Lab Med. 2004;42(5):467-74.

[164] De Caterina R, Massaro M, Scoditti E, Annunziata Carluccio M. Pharmacological modulation of vascular inflammation in atherothrombosis. Ann N Y Acad Sci. 2010;1207: 23-31.

[165] Albert MA, Glynn RJ, Ridker PM. Plasma concentration of C-reactive protein and the calculated Framingham Coronary Heart Disease Risk Score Circulation. 2003;108(2):161-5.

[166] Zairis MN, Ambrose JA, Lyras AG, Thoma MA, Psarogianni PK, Psaltiras PG, Kardoulas AD, Bibis GP, Pissimissis EG, Batika PC, DeVoe MC, Prekates AA, Foussas SG; GENERATION Study Group. C Reactive protein, moderate alcohol consumption, and long term prognosis after successful coronary stenting: Four year results from the GENERATION study. Heart. 2004;90(4):419-24.

[167] Sacanella E, Vázquez-Agell M, Mena MP, Antúnez E, Fernández-Solá J, Nicolás JM, Lamuela-Raventós RM, Ros E, Estruch R. Down-regulation of adhesion molecules and other inflammatory biomarkers after moderate wine con- 
sumption in healthy women: A randomized trial. Am J Clin Nutr. 2007;86(5):1463-9.

[168] Chiva-Blanch G, Urpi-Sarda M, Llorach R, RotchesRibalta M, Guillen M, Casas R, Arranz S, ValderasMartinez P, Portoles O, Corella D, Tinahones F, Lamuela-Raventos RM, Andres-Lacueva C, Estruch R. Differential effects of polyphenols and alcohol of red wine on the expression of adhesion molecules and inflammatory cytokines related to atherosclerosis: A randomized clinical trial. Am J Clin Nutr. 2012;95:326-34.

[169] Toth A, Sandor B, Papp J, Rabai M, Botor D, Horvath Z, Kenyeres P, Juricskay I, Toth K, Czopf L. Moderate red wine consumption improves hemorheological parameters in healthy volunteers. Clin Hemorheol Microcirc. 2014;56(1):13-23.

[170] Hannuksela ML, Liisanantti MK, Savolainen MJ. Effect of alcohol on lipids and lipoproteins in relation to atherosclerosis. Crit Rev Clin Lab Sci. 2002;39(3):225-83.

[171] Redmond EM, Morrow D, Kundimi S, Miller-Graziano CL, Cullen JP. Acetaldehyde stimulates monocyte adhesion in a P-selectin- and TNFalpha-dependent manner. Atherosclerosis. 2009;204:372-80.

[172] Mukamal KJ, Jensen MK, Grønbaek M, Stampfer MJ, Manson JE, Pischon T, Rimm EB. Drinking frequency, mediating biomarkers, and risk of myocardial infarction in women and men. Circulation. 2005;112(10): 1406-13.

[173] Mukamal KJ, Massaro JM, Ault KA, Mittleman MA, Sutherland PA, Lipinska I, Levy D, D'Agostino RB, Tofler GH. Alcohol consumption and platelet activation and aggregation among women and men: The Framingham Offspring Study. Alcohol Clin Exp Res. 2005;29(10): 1906-12.

[174] Chiva-Blanch G, Urpi-Sarda M, Ros E, Valderas-Martinez P, Casas R, Arranz S, Guillén M, Lamuela-Raventós RM, Llorach R, Andres-Lacueva C, Estruch R. Effects of red wine polyphenols and alcohol on glucose metabolism and the lipid profile: A randomized clinical trial Clin Nutr. 2013;32(2):200-6.

[175] Grønbaek M, Deis A, Sørensen TI, Becker U, Schnohr P, Jensen G. Mortality associated with moderate intakes of wine, beer, or spirits. BMJ. 1995;310(6988):1165-9.

[176] Mukamal KJ, Conigrave KM, Mittleman MA, Camargo CA Jr, Stampfer MJ, Willett WC, Rimm EB. Roles of drinking pattern and type of alcohol consumed in coronary heart disease in men. N Engl J Med. 2003;348(2):109-18.

[177] Mukamal KJ, Maclure M, Muller JE, Mittleman MA. Binge drinking and mortality after acute myocardial infarction. Circulation. 2005;112(25):3839-45.

[178] Cleophas TJ. Wine, beer and spirits and the risk of myocardial infarction: A systematic review. Biomed Pharmacother. 1999;53(9):417-23.

[179] Di Castelnuovo, A, Rotondo, S, Iacoviello, L, Donati, MB, de Gaetano, G. Meta-analysis of wine and beer consumption in relation to vascular risk. Circulation. 2002;105: 2836-44.

[180] Klatsky AL. Drink to your health? Sci American. 2003;288(2):75.

[181] Del Rio C, Prada C, Alvarez FJ. Beverage effects on patterns of alcohol consumption. Alcohol Clin Exp Res. 1995;19(6):1583-6.

[182] Puddey IB, Croft KD. Alcohol, stroke and coronary heart disease. Are there anti-oxidants and pro-oxidants in alco- holic beverages that might influence the development of atherosclerotic cardiovascular disease? Neuroepidemiol. 1999;18(6):292-302.

[183] Trevisan M, Ram M, Hovey K et al. Alcohol drinking patterns and myocardial infaction. American J Epidemiol. 2001;153:S97.

[184] Waterhouse AL. Wine phenolics. Ann NY Acad Sci. 2002;957:21-36.

[185] Hertog MGL, Hollman PCH, van de Putte B. Content of potentially anticarcinogenic flavonoids of tea infusions, wines and fruit juices. J Agric Food Chem. 1993;412: 1242-6.

[186] Croft KD, Puddey IB, Rakic V, Abu-Amsha R, Dimmitt $\mathrm{SB}$, Beilin, LJ. Oxidative susceptibility of low-density lipoproteins-influence of regular alcohol use. Alcohol Clin Exp Res. 1996;20(6):980-4.

[187] Kerry NL, Abbey M. Red wine and fractionated phenolic compounds prepared from red wine inhibit low density lipoprotein oxidation in vitro. Atherosclerosis. 1997;135: 93-102.

[188] Arranz S, Chiva-Blanch G, Valderas-Martínez P, MedinaRemón A, Lamuela-Raventós RM, Estruch R. Wine, beer, alcohol and polyphenols on cardiovascular disease and cancer. Nutrients. 2012;4(7):759-81.

[189] Genkinger, JM, Platz, EA, Hoffman, SC, Comstock, GW, Helzlsouer, KJ. Fruit, vegetable, and antioxidant intake and all-cause, cancer, and cardiovascular disease mortality in a community-dwelling population in Washington County, Maryland. Am J Epidemiol. 2004;160:1223-33.

[190] Estruch R, Ros E, Salas-Salvadó J, Covas MI, Corella D, Arós F, Gómez-Gracia E, Ruiz-Gutiérrez V, Fiol M, Lapetra J, Lamuela-Raventos RM, Serra-Majem L, Pintó X, Basora J, Muñoz MA, Sorlí JV, Martínez JA, Martínez-González MA; PREDIMED Study Investigators. Primary prevention of cardiovascular disease with a Mediterranean diet. N Engl J Med. 2013;368(14):1279-90.

[191] Tresserra-Rimbau A, Rimm EB, Medina-Remón A, Martínez-González MA, de la Torre R, Corella D, SalasSalvadó J, Gómez-Gracia E, Lapetra J, Arós F, Fiol M, Ros E, Serra-Majem L, Pintó X, Saez GT, Basora J, Sorlí JV, Martínez JA, Vinyoles E, Ruiz-Gutiérrez V, Estruch R, Lamuela-Raventós RM; PREDIMED Study Investigators. Inverse association between habitual polyphenol intake and incidence of cardiovascular events in the PREDIMED study. Nutr Metab Cardiovasc Dis. 2014;24(6): 639-47.

[192] Tresserra-Rimbau A, Rimm EB, Medina-Remón A, Martínez-González MA, López-Sabater MC, Covas MI, Corella D, Salas-Salvadó J, Gómez-Gracia E, Lapetra J, Arós F, Fiol M, Ros E, Serra-Majem L, Pintó X, Muñoz MA, Gea A, Ruiz-Gutiérrez V, Estruch R, Lamuela-Raventós RM; PREDIMED Study Investigators. Polyphenol intake and mortality risk: A re-analysis of the PREDIMED trial. BMC Med. 2014;12(1):77.

[193] Simopoulos AP. Mediterranean diets: What is so special about the diet of Greece? The scientific evidence. J Nutr. 2001;131:3065S-73S.

[194] Hu FB, Willett WC. Optimal diets for prevention of coronary heart disease. JAMA. 2002;288(20):2569-78.

[195] Sofi F, Cesari F, Abbate R, Gensini GF, Casini A. Adherence to Mediterranean diet and health status: Meta-analysis. $\mathrm{Br}$ Med J. 2008;37:a1344. 
[196] Sofi F, Abbate R, Gensini GF, Casini A. Accruing evidence on benefits of adherence to the Mediterranean diet on health: An updated systematic review and meta-analysis. Am J Clin Nutr. 2010;92(5):1189-96.

[197] Bhupathiraju SN, Tucker KL. Coronary heart disease prevention: Nutrients, foods, and dietary patterns. Clin Chim Acta. 2011;412(17-18):1493-514.

[198] Mente A, de Koning L, Shannon HS, Anand SS. A systematic review of the evidence supporting a causal link between dietary factors and coronary heart disease. Arch Intern Med. 2009; 169(7):659-69.

[199] de Lorgeril M, Salen P, Martin JL, Monjaud I, Delaye J, Mamelle N. Mediterranean diet, traditional risk factors, and the rate of cardiovascular complications after myocardial infarction: Final report of the Lyon Diet Heart Study. Circulation. 1999;99:779-85.

[200] Trichopoulou A, Lagiou P. Healthy traditional Mediterranean diet: An expression of culture, history, and lifestyle. Nutr Rev. 1997; 55:383-9.

[201] Kris-Etherton P, Eckel RH, Howard BV, St Jeor S, Bazzarre TL. AHA Science advisory: Lyon diet heart study benefits of a mediterranean-style, national cholesterol education program/american heart association step I dietary pattern on cardiovascular disease. Circulation. 2001;103: 1823-5.

[202] Knoops KT, de Groot LC, Kromhout D, Perrin AE, Moreiras-Varela O, Menotti A, van Staveren WA. Mediterranean diet, lifestyle factors, and 10-year mortality in elderly European men and women: The HALE project. JAMA. 2004;292(12):1433-9.

[203] Fung TT, Rexrode KM, Mantzoros CS, Manson JE, Willett WC, Hu FB. Mediterranean diet and incidence of and mortality from coronary heart disease and stroke in women. Circulation. 2009;119(8): 1093-100.

[204] Martínez-González MA, García-López M, Bes-Rastrollo M, Toledo E, Martínez-Lapiscina EH, Delgado-Rodriguez M, Vazquez Z, Benito S, Beunza JJ. Mediterranean diet and the incidence of cardiovascular disease: A Spanish cohort. Nutr Metab Cardiovasc Dis. 2011;21(4):237-44.

[205] Nordmann AJ, Suter-Zimmermann K, Bucher HC, Shai I, Tuttle KR, Estruch R, Briel M. Meta-analysis comparing mediterranean to low-fat diets for modification of cardiovascular risk factors. Am J Med. 2011;124(9): 841-51.

[206] Yang J, Farioli A, Korre M, Kales SN. Modified mediterranean diet score and cardiovascular risk in a North American working population. PLoS One. 2014;9(2): e87539 doi: 101371/journalpone0087539

[207] Strandberg TE, Strandberg AY, Salomaa VV, Pitkälä K, Tilvis RS, Miettinen TA. Alcoholic beverage preference, 29-year mortality, and quality of life in men in old age. J Gerontol A Biol Sci Med Sci. 2007;62(2):213-18.

[208] Hansen-Krone IJ, Brækkan SK, Enga KF, Wilsgaard T, Hansen JB. Alcohol consumption, types of alcoholic beverages and risk of venous thromboembolism - the Troms $\varnothing$ Study. Thromb Haemost. 2011;106(2):272-8.

[209] Levantesi G, Marfisi R, Mozaffarian D, Franzosi MG, Maggioni A, Nicolosi GL, Schweiger C, Silletta M, Tavazzi L, Tognoni G, Marchioli R. Wine consumption and risk of cardiovascular events after myocardial infarction: Results from the GISSI-Prevenzione trial. Int J Cardiol. 2011; Jul 5 [Epub ahead of print] PubMed PMID: 21737162.
[210] Rodriguez AF, Banegas JR, Garcia CC, del Rey CJ. Lower consumption of wine and fish as a possible explanation for higher ischaemic heart disease mortality in Spain's Mediterranean region. Int J Epidemiol. 1996;25: 1196-201.

[211] Hansel B, Thomas F, Pannier B, Bean K, Kontush A, Chapman MJ, Guize L, Bruckert E. Relationship between alcohol intake, health and social status and cardiovascular risk factors in the Urban Paris-Ile-de-France Cohort: Is the cardioprotective action of alcohol a myth? Eur J Clin Nutr. 2010;64(6):561-8.

[212] Levantesi G, Marfisi R, Mozaffarian D, Franzosi MG, Maggioni A, Nicolosi GL, Schweiger C, Silletta M, Tavazzi L, Tognoni G, Marchioli R. Wine consumption and risk of cardiovascular events after myocardial infarction: Results from the GISSI-Prevenzione trial. Int J Cardiol. 2013;163(3): 282-7.

[213] Klatsky AL, Armstrong MA, Kipp H Correlates of alcoholic beverage preference: Traits of persons who choose wine, liquor or beer. Br J Addict. 1990;85(10):1279-89.

[214] Grønbaek M. Alcohol consumption and mortality. Type of drink has been shown to matter. BMJ. 1999;319(7219): 1267-8.

[215] Mortensen EL, Jensen HH, Sanders SA, Reinisch JM. Better psychological functioning and higher social status may largely explain the apparent health benefits of wine: A study of wine and beer drinking in young Danish adults ArchIntern Med. 2001;161(15):1844-8.

[216] Barefoot JC, Gronbaek M, Feaganes JR, McPherson RS, Williams RB, Siegler IC. Alcoholic beverage preference, diet, and health habits in the UNC Alumni Heart Study. Am J Clin Nutr. 2002;76: 466-72.

[217] Hansel B, Roussel R, Diguet V, Deplaude A, Chapman MJ, Bruckert E. Relationships between consumption of alcoholic beverages and healthy foods: The French supermarket cohort of 196,000 subjects. Eur J Prev Cardiol. 2013; Sep 24 [Epub ahead of print] PubMed PMID: 24065742

[218] Droste DW, Iliescu C, Vaillant M, Gantenbein M, De Bremaeker N, Lieunard C, Velez T, Meyer M, Guth T, Kuemmerle A, Gilson G, Chioti A. A daily glass of red wine associated with lifestyle changes independently improves blood lipids in patients with carotid arteriosclerosis: Results from a randomized controlled trial. Nutr J. 2013; 12(1): 147 .

[219] Li S, Chiuve SE, Flint A, Pai JK, Forman JP, Hu FB, Willett WC, Mukamal KJ, Rimm EB. Better diet quality and decreased mortality among myocardial infarction survivors. JAMA Intern Med. 2013;173(19):1808-18.

[220] Baigent C, Keech A, Kearney PM, Blackwell L, Buck G, Pollicino C, Kirby A, Sourjina T, Peto R, Collins R, Simes R; Cholesterol Treatment Trialists' (CTT) Collaborators. Efficacy and safety of cholesterol-lowering treatment: Prospective meta-analysis of data from 90,056 participants in 14 randomised trials of statins. Lancet. 2005;366(9493):1267-78.

[221] Gea A, Bes-Rastrollo M, Toledo E, Garcia-Lopez M, Beunza JJ, Estruch R, Martinez-Gonzalez MA. Mediterranean alcohol-drinking pattern and mortality in the SUN (Seguimiento Universidad de Navarra) Project: A prospective cohort study. Br J Nutr. 2014; 111(10):1871-80.

[222] Meisinger C, Baumert J, Khuseyinova N, Loewel H, Koenig W. Plasma oxidized low-density lipoprotein, a strong pre- 
dictor for acute coronary heart disease events in apparently healthy, middle-aged men from the general population. Circulation. 2005;112(5):651-7.

[223] Aviram M. Interaction of oxidized low density lipoprotein with macrophages in atherosclerosis, and the antiatherogenicity of antioxidants. Eur J Clin Chem Clin Biochem. 1996;34(8):599-608.

[224] Maxwell S, Cruikshank A, Thorpe G. Red wine and antioxidant activity in serum. Lancet. 1994;344:193-4.

[225] Fuhrman B, Lavy A, Aviram M. Consumption of red wine with meals reduces the susceptibility of human plasma and low density-lipoprotein to lipid peroxidation. Am J Clin Nutr. 1995;61:549-54.

[226] Abu-Amsha R, Croft KD, Puddey IB, Proudfoot JM, Beilin, LJ. Phenolic content of various beverages determines the extent of inhibition of human serum and low-density lipoprotein oxidation in vitro: Identification and mechanism of action of some cinnamic acid derivatives from red wine. Clin Sci (Lond). 1996;91(4):449-58.

[227] Paganga G, Rice-Evans CA. The identification of flavonoids as glycosides in human plasma. FEBS Lett. 1997;401:78-82.

[228] Witztum JL, Steinberg D. Role of oxidized low density lipoprotein in atherogenesis. J Clin Invest. 1991;88: 1785-92.

[229] Abu-Amsha Caccetta R, Burke V, Mori TA, Beilin LJ, Puddey IB, Croft KD. Red wine polyphenols, in the absence of alcohol, reduce lipid peroxidative stress in smoking subjects. Free Radic Biol Med. 2001;30(6): 636-42.

[230] Miyagi Y, Miwa K, Inoue H. Inhibition of human lowdensity lipoprotein oxidation by flavonoids in red wine and grape juice. Am J Cardiol. 1997;80(12):1627-31.

[231] Nigdikar SV, Williams NR, Griffin BA, Howard AN. Consumption of red wine polyphenols reduces the susceptibility of low-density lipoproteins to oxidation in vivo. Am J Clin Nutr. 1998; 68(2):258-65.

[232] Blackhurst DM, Marais AD. Concomitant consumption of red wine and polyunsaturated fatty acids in edible oil does not influence the peroxidation status of chylomicron lipids despite increasing plasma catechin concentration. Nutr Metab Cardiovasc Dis. 2006;16(8):550-8.

[233] Pignatelli P, Ghiselli A, Buchetti B, Carnevale R, Natella F, Germanò G, Fimognari F, Di Santo S, Lenti L, Violi F. Polyphenols synergistically inhibit oxidative stress in subjects given red and white wine. Atherosclerosis. 2006;188(1):77-83.

[234] Estruch R, Sacanella E, Mota F, Chiva-Blanch G, Antúnez E, Casals E, Deulofeu R, Rotilio D, Andres-Lacueva C, Lamuela-Raventos RM, de Gaetano G, Urbano-Marquez A. Moderate consumption of red wine, but not gin, decreases erythrocyte superoxide dismutase activity: A randomised cross-over trial. Nutr Metab Cardiovasc Dis. 2011;21(1): 46-53.

[235] van der Gaag, MS, Sierksma, A, Schaafsma, G, van Tol, A, Geelhoed-Mieras, T, Bakker, M, Hendriks, HF. Moderate alcohol consumption and changes in postprandial lipoproteins of premenopausal and postmenopausal women: A diet-controlled, randomized intervention study. J Womens Health Gend Based Med. 2000;9(6):607-16.

[236] Addolorato G, Leggio L, Ojetti V, Capristo E, Gasbarrini G, Gasbarrini A. Effects of short-term moderate alcohol administration on oxidative stress and nutritional status in healthy males. Appetite. 2008;50(1):50-6.

[237] Seigneur M, Bonnet J, Dorian B, Benchimol D, Drouillet F, Gouverneur G, Larrue J, Crockett R, Boisseau M-R, Ribereau-Gayon P. Effect of the consumption of alcohol, white wine and red wine on platelet function and serum lipids. J Appl Cardiol. 1990; 5:215-22.

[238] Polette A, Lemaitre D, Lagarde M, Vericel E. N-3 fatty acidinduced lipid peroxidation in human platelets is prevented by catechins. Thromb Haemost. 1996;75(6):945-9.

[239] De Lange DW, Van Golden PH, Scholman WL, Kraaijenhagen RJ, Akkerman JW, Van De Wiel A. Red wine and red wine polyphenolic compounds but not alcohol inhibit ADP-induced platelet aggregation. Eur J Intern Med. 2003;14(6):361-6.

[240] Rabai M, Toth A, Kenyeres P, Mark L, Marton Z, Juricskay I, Toth K, Czopf L. In vitro hemorheological effects of red wine and alcohol-free red wine extract. Clin Hemorheol Microcirc. 2010;44(3):227-36.

[241] Landolfi R, Mower RL, Steiner M. Modification of platelet function and arachidonic acid metabolism by bioflavonoids Structure-activity relations. Biochem Pharmacol. 1984;33(9):1525-30.

[242] Da Luz PL, Serrano JR CV, Chacra AP, Monteiro HP, Yoshida VM, Furtado M, Ferreira S, Guthierrez P, Pileggi, F. The effect of red wine on experimental atherosclerosis: Lipid-independent protection. Exp Mol Pathol. 1999;65:150-9.

[243] Demrow HS, Folts, JD. Gastric or IV administration of French red wine but not white wine inhibitions in vivo platelet activity and thrombosis in stenosed canine coronary arteries. J Am Coll Cardiol. 1994;23:49A.

[244] Demrow HS, Slane PR, Folts JD. Administration of wine and grape juice inhibits in vivo platelet activity and thrombosis in stenosed canine coronary arteries. Circulation. 1995;91(4):1182-8.

[245] Maalej N, Demrow HS, Slane PR, Folts JD. Antithrombotic effect of flavonoids in red wine. In: Watkins TR, editor. Wine: Nutritional and therapeutic benefits. Developed from a symposium sponsored by the Division of Agricultural and Food Chemistry. 1997:247-60.

[246] Wang Z, Huang Y, Zou J, Cao K, Xu Y, Wu JM. Effects of red wine and wine polyphenol resveratrol on platelet aggregation in vivo and in vitro. Int J Mol Med. 2002;9(1):77-9.

[247] De Curtis A, Murzilli S, Di Castelnuovo A, Rotilio D, Donati MB, De Gaetano G, Iacoviello L. Alcohol-free red wine prevents arterial thrombosis in dietary-induced hypercholesterolemic rats: Experimental support for the 'French paradox'. J Thromb Haemost. 2005;3(2):346-50.

[248] Renaud SC, Ruf JC. Effects of alcohol on platelet functions. Clin Chim Acta. 1996;246:77-89.

[249] Ruf JC, Berger JL, Renaud S. Platelet rebound effect of alcohol withdrawal and wine drinking in rats-relation to tannins and lipid peroxidation. Arterioscler Thromb Vasc Biol. 1995;15:140-4.

[250] Puddey IB, Croft K. Alcoholic beverages and lipid peroxidation: Relevance to cardiovascular disease. Addict Biol. 1997;2 (3):269-76.

[251] van de Wiel A, van Golde PM, Kraaijenhagen RJ, von dem Borne PA, Bouma BN, Hart HC. Acute inhibitory effect of alcohol on fibrinolysis. Eur J Clin Invest. 2001;31(2): 164-70. 
[252] Mansvelt EP, van Velden DP, Fourie E, Rossou, M, van Rensburg SJ, Smuts CM. The in vivo antithrombotic effect of wine consumption on human blood platelets and hemostatic factors. Ann NY Acad Sci. 2002;957:329-32.

[253] Abou-Agag LH, Aikens ML, Tabengwa EM, Benza RL, Shows SR, Grenett HE, Booyse FM. Polyphyenolics increase t-PA and u-PA gene transcription in cultured human endothelial cells. Alcohol Clin Exp Res. 2001;25(2): 155-62.

[254] Mano T, Masuyama T, Yamamoto K, Naito J, Kondo H, Nagano R, Tanouchi J, Hori M, Inoue M, Kamada T. Endothelial dysfunction in the early stage of atherosclerosis precedes appearance of intimal lesions assessable with intravascular ultrasound. Am Heart J. 1996;131(2):231-8.

[255] Di Corleto PE, Soyombo AA. The role of the endothelium in atherogenesis. Curr Opin Lipidol. 1993;4:364-72.

[256] Moncada S, Palmer RM, Higgs EA. Nitric oxide: Physiology, pathophysiology, and pharmacology. Pharmacol Rev. 1991;43(2):109-42.

[257] Leighton F, Cuevas A, Guasch V, Perez DD, Strobel P, San Martin A, Urzu, U, Diez MS, Foncea R, Castillo O, Mizon C, Espinoza MA Urquiaga I, Rozowski J, Maiz A, Germain, A. Plasma polyphenols and antioxidants, oxidative DNA damage and endothelial function in a diet and wine intervention study in humans. Drugs Exp Clin Res. 1999;25(2-3): 133-41.

[258] Cuevas AM, Guasch V, Castillo O, Irribarra V, Mizon C, San Martin A, Strobel P, Perez D, Germain AM, Leighton F. A high-fat diet induces and red wine counteracts endothelial dysfunction in human volunteers. Lipids. 2000;35(2): 143-8.

[259] Agewall S, Wright S, Doughty RN, Whalley GA, Duxbury $\mathrm{M}$, Sharpe N. Does a glass of red wine improve endothelial function? Eur Heart J. 2000;21(1):74-8.

[260] Hashimoto Y, Futamura A, Nakarai H, Nakahara K. Effects of the frequency of alcohol intake on risk factors for coronary heart disease. Eur J Epidemiol. 2001;17(4):307-12.

[261] Karatzi K, Papamichael C, Aznaouridis K, Karatzis E, Lekakis J, Matsouka C, Boskou G, Chiou A, Sitara M, Feliou G, Kontoyiannis D, Zampelas A, Mavrikakis M. Constituents of red wine other than alcohol improve endothelial function in patients with coronary artery disease. Coron Artery Dis. 2004;15(8):485-90.

[262] Whelan AP, Sutherland WH, McCormick MP, Yeoman DJ, de Jong SA, Williams MJ. Effects of white and red wine on endothelial function in subjects with coronary artery disease. Intern Med J. 2004;34(5):224-8.

[263] Boban M, Modun D, Music I, Vukovic J, Brizic I, Salamunic I, Obad A, Palada I, Dujic Z. Red wine induced modulation of vascular function: Separating the role of polyphenols, ethanol, and urates. J Cardiovasc Pharmacol. 2006;47(5):695-701.

[264] Karatzi KN, Papamichael CM, Karatzis EN, Papaioannou TG, Aznaouridis KA, Katsichti PP, Stamatelopoulos KS, Zampelas A, Lekakis JP, Mavrikakis ME. Red wine acutely induces favorable effects on wave reflections and central pressures in coronary artery disease patients. Am J Hypertens. 2005;18(9 Pt 1):1161-7.

[265] Karatzi K, Papamichael C, Karatzis E, Papaioannou TG, Voidonikola PT, Vamvakou GD, Lekakis J, Zampelas A. Postprandial improvement of endothelial function by red wine and olive oil antioxidants: A synergistic effect of components of the Mediterranean diet. J Am Coll Nutr. 2008;27(4):448-53.

[266] Tousoulis D, Ntarladimas I, Antoniades C, Vasiliadou C, Tentolouris C, Papageorgiou N, Latsios G, Stefanadis C. Acute effects of different alcoholic beverages on vascular endothelium, inflammatory markers and thrombosis fibrinolysis system. Clin Nutr. 2008;27(4):594-600.

[267] Kiviniemi TO, Saraste A, Toikka JO, Saraste M, Raitakari OT, Pärkkä JP, Lehtimäki T, Hartiala JJ, Viikari J, Koskenvuo JW. A moderate dose of red wine, but not de-alcoholized red wine increases coronary flow reserve. Atherosclerosis. 2007; 195(2):e176-81.

[268] Andriambeloson E, Magnier C, Haan-Archipoff G, Lobstein A, Anton R, Beretz A, Stoclet JC, Andriantsitohaina R. Natural dietary polyphenolic compounds cause endothelium-dependent vasorelaxation in rat thoracic aorta. J Nutr. 1998;128:2324-33,

[269] Diebolt M, Bucher B, Andriantsitohaina R. Wine polyphenols decrease blood pressure, improve NO vasodilatation, and induce gene expression. Hypertension. 2001;38(2):159-65.

[270] Fitzpatrick DF, Hirschfield SL, Coffey RG. Endotheliumdependent vasorelaxing activity of wine and other grape products. Am J Physiol. 1993;265(2 Pt 2):H774-8.

[271] Stein JH, Keevil JG, Wiebe DA, Aeschlimann S, Folts JD. Purple grape juice improves endothelial function and reduces the susceptibility of LDL cholesterol to oxidation in patients with coronary artery disease. Circulation. 1999;100(10):1050-5.

[272] Wallerath T, Deckert G, Ternes T, Anderson H, Li H, Witte K, Förstermann U. Resveratrol, a polyphenolic phytoalexin present in red wine, enhances expression and activity of endothelial nitric oxide synthase Circulation. 2002;106:1652-58

[273] Keaney JF Jr, Vita JA. Atherosclerosis, oxidative stress, and antioxidant protection in endothelium-derived relaxing factor action. Prog Cardiovasc Dis. 1995;38(2):129-54.

[274] Kubes P, Suzuki M, Granger DN. Nitric oxide: An endogenous modulator of leukocyte adhesion. Proc Natl Acad Sci USA. 1991;88(11):4651-5.

[275] Davenpeck KL, Gauthier TW, Lefer AM. Inhibition of endothelial-derived nitric oxide promotes P-selectin expression and actions in the rat microcirculation. Gastroenterology. 1994;107(4):1050-8.

[276] De Caterina R, Libby P, Peng HB, Thannickal VJ, Rajavashisth TB, Gimbrone MA Jr, Shin WS, Liao JK. Nitric oxide decreases cytokine-induced endothelial activation. Nitric oxide selectively reduces endothelial expression of adhesion molecules and proinflammatory cytokines. J Clin Invest. 1995;96(1):60-8.

[277] Zou JG, Wang ZR, Huang YZ, Cao KJ, Wu JM. Effect of red wine and wine polyphenol resveratrol on endothelial function in hypercholesterolemic rabbits. Int J Mol Med. 2003;11(3):317-20.

[278] Corder R, Douthwaite JA, Lees DM, Khan NQ, Viseu Dos Santos AC, Wood EG, Carrier MJ. Endothelin-1 synthesis reduced by red wine. Nature 2001;414(6866):863-4.

[279] Estruch R, Sacanella E, Badia E, Antúnez E, Nicolás JM, Fernández-Solá J, Rotilio D, de Gaetano G, Rubin E, Urbano-Márquez A. Different effects of red wine and gin consumption on inflammatory biomarkers of atherosclerosis: A prospective randomized crossover trial 
Effects of wine on inflammatory markers. Atherosclerosis. 2004; 175(1):117-23.

[280] Sacanella E, Estruch R. The effect of alcohol consumption on endothelial adhesion molecule expression. Addict Biol. 2003;8:371-8.

[281] Schelling P, Fischer H, Ganten D. Angiotensin and cell growth: A link to cardiovascular hypertrophy? J Hypertens. 1991;9(1):3-15.

[282] Takahashi T, Kawahara Y, Okuda M, Ueno H, Takeshita A, Yokoyama, M. Angiotensin II stimulates mitogen-activated protein kinases and protein synthesis by a Ras-independent pathway in vascular smooth muscle cells. J Biol Chem. 1997;272(25):16018-22.

[283] Moon SK, Cho GO, Jung SY, Gal SW, Kwon TK, Lee YC, Madamanchi NR, Kim CH. Quercetin exerts multiple inhibitory effects on vascular smooth muscle cells: Role of ERK1/2, cell-cycle regulation, and matrix metalloproteinase-9. Biochem Biophys Res Commun. 2003;301(4):1069-78.

[284] Hernandez-Ledesma B, Martin-Alvarez PJ, Pueyo E. Assessment of the spectrophotometric method for determination of angiotensin-converting-enzyme activity: Influence of the inhibition type. J Agric Food Chem. 2003;51(15):4175-9.

[285] Whitehead TP, Robinson D, Allaway S, Syms J, Hale A. Effect of red wine ingestion on the antioxidant capacity of serum. Clin Chem. 1995;41(1):32-5.

[286] Caccetta RA, Croft KD, Beilin LJ, Puddey IB. Ingestion of red wine significantly increases plasma phenolic acid concentrations but does not acutely affect ex vivo lipoprotein oxidizability. Am J Clin Nutr. 2000;71(1):67-74.

[287] Benito S, Lopez D, Saiz MP, Buxaderas S, Sánchez J, PuigParellada P, Mitjavila MT. A flavonoid-rich diet increases nitric oxide production in rat aorta. $\mathrm{Br} \mathrm{J}$ Pharmacol. 2002;135:910-16.

[288] Chen CK, Pace-Asciak CR. Vasorelaxing activity of resveratrol and quercetin in isolated rat aorta. Gen Pharmacol. 1996;27:363-6.

[289] Cishek MB, Galloway MT, Karim M, German JB, Kappagoda CT. Effect of red wine on endothelium-dependent relaxation in rabbits. Clin Sci (Lond). 1997;93:507-11.

[290] Wallerath T, Li H, Gödtel-Ambrust U, Schwarz PM, Förstermann, U. A blend of polyphenolic compounds explains the stimulatory effect of red wine on human endothelial NO synthase. Nitric Oxide. 2005;12(2):97-104.

[291] Sánchez M, Galisteo M, Vera R, Villar IC, Zarzuelo A, Tamargo J, Pérez-Vizcaíno F, Duarte J. Quercetin downregulates NADPH oxidase, increases eNOS activity and prevents endothelial dysfunction in spontaneously hypertensive rats. J Hypertens. 2006;24(1):75-84.

[292] Negishi H, Xu JW, Ikeda K, Njelekela M, Nara Y, Yamori Y. Black and green tea polyphenols attenuate blood pressure increases in stroke-prone spontaneously hypertensive rats. J Nutr. 2004;134(1):38-42.

[293] Garcia-Saura, MF, Galisteo M, Villar IC, Bermejo A, Zarzuelo A, Vargas F, Duarte J. Effects of chronic quercetin treatment in experimental renovascular hypertension. Mol Cell Biochem. 2005;270:147-55.

[294] Duarte J, Jimenez R, O’Valle F, Galisteo M, Pérez-Palencia R, Vargas F, Pérez-Vizcaíno F, Zarzuelo A, Tamargo J. Protective effects of the flavonoid quercetin in chronic nitric oxide deficient rats. J Hypertens. 2002;20:1843-54.
[295] Liu Z, Song Y, Zhang X, Liu Z, Zhang W, Mao W, Wang W, Cui W, Zhang X, Jia X, Li N, Han C, Liu C. Effects of trans-resveratrol on hypertension-induced cardiac hypertrophy using the partially nephrectomized rat model. Clin Exp Pharmacol Physiol. 2005;32:1049-54.

[296] Malinowska J, Olas B. Effect of resveratrol on hemostatic properties of human fibrinogen and plasma during model of hyperhomocysteinemia. Thromb Res. 2010;126(5):e37982.

[297] Malinowska J, Olas B. Response of blood platelets to resveratrol during a model of hyperhomocysteinemia. Platelets. 2011;22(4): 277-83.

[298] Koga T, Meydani M. Effect of plasma metabolites of (+)catechin and quercetin on monocyte adhesion to human aortic endothelial cells. Am J Clin Nutr. 2001;73(5):941-8.

[299] Williamson G, Barron D, Shimoi K, Terao J. In vitro biological properties of flavonoid conjugates found in vivo. Free Radic Res. 2005;39(5):457-69.

[300] Williamson G, Manach C. Bioavailability and bioefficacy of polyphenols in humans II Review of 93 intervention studies. Am J Clin Nutr. 2005;81(1 Suppl):243S-55S.

[301] World Health Orgnisation. Global status report on alcohol. Switzerland: World Health Organisation; 2011.

[302] Rehm J, Room R, Graham K, Monteiro M, Gmel G, Sempos CT. The relationship of average volume of alcohol consumption and patterns of drinking to burden ofdisease: An overview. Addiction. 2003;98(9):1209-28.

[303] Rehm J, Sempos CT, Trevisan M. Average volume of alcohol consumption, patterns of drinking and risk of coronary heart disease-a review. J Cardiovasc Risk. 2003;10:15-20.

[304] McElduff P, Dobson AJ. How much alcohol and how often? Population based case-control study of alcohol consumption and risk of a major coronary event. Br Med J. 1997;314(7088):1159-64.

[305] Britton A, Marmot M. Different measures of alcohol consumption and risk of coronary heart disease and all-cause mortality: 11-year follow-up of the Whitehall II Cohort Study. Addiction. 2004; 99(1):109-16.

[306] Tolstrup JS, Jensen MK, Tjønneland AM, Overvad K, Mukamal KJ, Grønbaek M. [A prospective study of drinking habits and coronary heart disease in middle-aged Danish men and women - secondary publication]. Ugeskr Laeger. 2006;168(45):3916-9.

[307] van de Wiel A, de Lange DW. Cardiovascular risk is more related to drinking pattern than to the type of alcoholic drinks. Neth J Med. 2008;66(11):467-73.

[308] Bagnardi V, Zatonski W, Scotti L, La Vecchia C, Corrao G. Does drinking pattern modify the effect of alcohol on the risk of coronary heart disease? Evidence from a metaanalysis. J Epidemiol Community Health. 2008;62(7):6159.

[309] Wannamethee G, Shaper AG. Alcohol and sudden cardiac death. Br Heart J. 1992;68(5):443-8.

[310] Kauhanen J, Kaplan GA, Goldberg DE, Salonen JT. Beer binging and mortality: Results from the Kuopio ischaemic heart disease risk factor study, a prospective population based study. BMJ. 1997; 315(7112):846-51.

[311] Alvarez FJ, del Río MC. Gender differences in patterns of alcohol consumption in Spain. Alcohol Clin Exp Res. 1994;18(6):1342-57.

[312] Grønbæk M, Johansen D, Becker U, Hein HO, Schnohr P, Jensen G, Vestbo J, Sørensen T. Changes in Alcohol Intake 
and Mortality: A Longitudinal Population-based Study. Epidemiology. 2004;15(2):222-8.

[313] Friesema IH, Zwietering PJ, Veenstra MY, Knottnerus JA, Garretsen HF, Kester AD, Lemmens PH.The effect of alcohol intake on cardiovascular disease and mortality disappeared after taking lifetime drinking and covariates into account. Alcohol Clin Exp Res. 2008;232(4):645-51.

[314] Breslow RA, Graubard BI. Prospective study of alcohol consumption in the United States: Quantity, frequency, and cause-specific mortality. Alcohol Clin Exp Res. 2008;32(3):513-21.

[315] Finegold JA, Asaria P, Francis DP. Mortality from ischaemic heart disease by country, region, and age: Statistics from World Health Organisation and United Nations. Int J Cardiol. 2012;168 (2):934-45.

[316] Australian Government. Australia to 2050: Future challenges. The 2010 intergenerational report. Canberra: Commonwealth of Australia; 2010.

[317] Doll R, Peto R, Boreham J, Sutherland I. Mortality in relation to alcohol consumption: A prospective study among male British doctors. Int J Epidemiol. 2005;34(1):199-204.

[318] Beulens JW, Algra A, Soedamah-Muthu SS, Visseren FL, Grobbee DE, van der Graaf Y; SMART Study Group. Alcohol consumption and risk of recurrent cardiovascular events and mortality in patients with clinically manifest vascular disease and diabetes mellitus: The Second Manifestations of ARTerial (SMART) disease study. Atherosclerosis. 2010;212:281-6.

[319] Gmel G, Gutjahr E, Rehm J. How stable is the risk curve between alcohol and all-cause mortality and what factors influence the shape? A precision-weighted hierarchical meta-analysis. Eur J Epidemiol. 2003;18(7):631-42.

[320] Wellmann J, Heidrich J, Berger K, Döring A, Heuschmann PU, Keil U. Changes in alcohol intake and risk of coronary heart disease and all-cause mortality in the MONICA/KORA-Augsburg cohort 1987-97. Eur J Cardiovasc Prev Rehabil. 2004;11(1):48-55.

[321] Jayasekara H, English DR, Room R, MacInnis RJ. Alcohol consumption over time and risk of death: A systematic review and meta-analysis. Am J Epidemiol. 2014;179(9): 1049-59.

[322] Sierksma A, van der Gaag MS, van Tol A, James RW, Hendriks HF. Kinetics of HDL cholesterol and paraoxonase activity in moderate alcohol consumers. Alcohol Clin Exp Res. 2002;26(9):1430-35.

[323] Sierksma A, Vermunt SH, Lankhuizen IM, van der Gaag MS, Scheek LM, Grobbee DE, van Tol A, Hendriks HF. Effect of moderate alcohol consumption on parameters of reverse cholesterol transport in postmenopausal women. Alcohol Clin Exp Res. 2004;28(4):662-66. 